\title{
Türk Şiirinde Nazire
}

\author{
KEMAL YAVUZ*
}

\author{
Nazire in Turkish Poetry
}

\section{Ö Z E T}

Nazire, bir şiire başka bir şairin ayn konu ve vezin, kafiye veya redifle yazılan şiirlerin genel adıdır. Cahiliye devrinde varh $\breve{g}$ indan bahsedilen nazire, ilk defa peygamberimiz zamanında ortaya çıkmıştır. Fars ve Türk edebiyatlarında ise XII. yüzyılda görülmeye başlanmıştır. Türk edebiyatında ilk örnekleri Ahmed-i Yesevînin şiirlerine ögrencisi Hakim Süleyman Ata tarafindan yazılarak ortaya konmuştur. Anadolu'da XIII. yüzyıldan sonra gelişen Türk edebiyatı için bu bir örnek olmuş ve Yunus Emre de Ahmed-i Yesevîn nin şïrlerine nazireler yazmıştır. Daha sonra gelen şairlerden Ahmedî ve Nesîmî Yunus'un şiirlerine nazireler yazarlar. Bu şairlerden başlayarak XV. yüzyılda devam eden nazirecilik Fatih devri şairlerini de etkilemiştir. Özelikle Necâtînnin şiirleri zamanında ve daha sonraları pek çok şair tarafından tanzir edilmiştir. Bu durum asırlar aşırı bir şekilde zamanımıza kadar gelmiştir. Ayrıca Misır ve Çağatay bölgelerinde de önde gelen bazı şairler tarafından nazire şiirler de yazılmıştır.

Nazire Türk şiirinde pek çok şairin yetişmesini să̆ladı̆̆ gibi bu şiirlerin yer aldığı eserlerin de ortaya çıkmasına yol açmıştır. Böylece nazire mecmuaları Mecmûatü'n-Nazâir adlı eserle XV. yüzyıldan itibaren görülmeye başlanmıştır. Bunu XVI. yüzyılda yazılan Mecmaü'n-Nezâir, Câimü'nNezâir, Pervane Bey Mecmuası takip etmiştir. XVII. yüzyılda ise Metâliü'n-Nezâir'in yazıldığın görüyoruz. Bundan sonra ise şiir meraklıları tarafindan pek çok mecmua ortaya konmuştur.

A N A H T A R K E L İM EL E R

Türk şiiri, nazire, nazire mecmuaları.

\section{A B S T R A C T}

Nazire is the common name of the poetries that are written in the same subject, meter and ryhme to an another poetry. Nazire is mentioned to be existed in Cahiliyye period but it first appeared in the prophet Mohammed's time. It occured in Arabic and Persian literatures in 12th century. First samples of Turkish literature are written by Hakim Süleyman Ata to his master, Ahmed-i Yesevi's poems. It set an example to the literature developing in Anatolia and Yunus Emre wrote nazires to Ahmed-i Yesevi's poems. Later, Ahmedi and Nesimi wrote nazires to Yunus Emre's poems. Starting with these poets, in 15th century, nazire writing affected other poets in Fatih's period. Especially, to Necati's poems are written nazires by many other poets both in his time and after his time. This continued for centuries up until today. Also, in Egypt and Chagatay regions, nazires are written by some leading poets.

Nazire not only helped the improvement of many young poets but also it enabled the formation of the works that these poems are in. It is seen with the Mecmuatu'nNazair as from the 15th century. Mecmau'n-Nezair, Camiü'n-Nezair, Pervane Bey Mecmuasi followed it. Metaliü'n-Nezair is written in 17th century. After that, many mecmuas are formed by the people who are interested in poetry.

K E Y W O R D S

Turkish poetry, nazire, nazire mecmuas.

Bir şairin şiirine sonradan bir başka şair veya şairin kendisi tarafından, kafiyeleri veya kafiye ve redifleri aynı olan, aynı vezin ve konuda yazılan, çoklukla gazel ve kasidelerde görülen benzer şiirlere nazire veya cevap denir. Nazirenin genellikle, aynı dilde ve şivelerinde olması

\footnotetext{
" Prof. Dr., İstanbul Üniversitesi Edebiyat Fakültesi Türk Dili ve Edebiyatı Bölümü, İstanbul (kemalyavuz05@gmail.com).
} 
gerekir. Arap edebiyatında Cahiliye devrinden itibaren görülen nazire, İslâmî dönemde Hassan bin Sabit'in hicretin dokuzuncu yılında, Temim Kabilesi'nden bir şairin söylediği şiire aynı vezin, aynı kafiye ve aynı konuda söylediği şiirle daha da açı̆̆a çıkmıştır (İslam Âlimleri Ansiklopdisi 1/332-334, II/14-16). Daha sonra Ka'b bin Züheyr'in "Bânet Süâd = Sevgili Uzaklaştı" adındaki Peygamber için yazdığı natına yazılan şiirlerle en geniş şekilde görülmeye başlanmış ve kesintisiz devam edip gelmiştir. Ancak terim olarak nazire yerine "muâraza" yanında "ihtiza" ve "muhâkât" kelimeleri de kullanılmış, çok sonraları "taklid, nazir, mesîl" terimlerine de yer verilmiştir (Durmuş 2006: 455 vd.9). Fars edebiyatında ise, nazire, "cevab" kelimesi ile karşılanmış, ayrıca "istikbâl" ve "tazmîn" gibi terimler de kullanılmıştır. Fars edebiyatında da ilk nazire örnekleri on ikinci yüzyılda görülmeye başlanmıştır (Çiçekler 2006: 457).

Edebiyatta şairlerin yetişmeleri, güzel şiirlerin taklit edilmesi ve sanatkârın kendini her yönü ile geliştirerek ortaya özgün eserler koyması ile sağlanmıştır. Bu açıdan bakınca nazirelerin edebiyatta büyük bir itici güç olduğunu görürüz. Şair bu ilk devrinde bir çırak gibidir; hatta şiir bilgisinin genişlemesi, hayat tecrübe ve şartlarının sanata yönelmesi, bulunduğu ortama göre şairler meclisine devamı, şairlerle olan ilgisi veya çok okuması onun, kalfalık devrini de geçerek ustalık dönemine ayak basması ile şahsiyetini kazanmasına yol açar. Bütün bunlarda dili ne şekilde kullanması gerektiğini öğrendiği gibi kelime bilgisi zenginleşir, kafiyenin dar ve geniş zeminlerine de vâkıf olur. Gönlü, aklı ve kulağı da ses ve kelimeye karşı ilgili olur ve hafızası genişler. Büyük sanatkârlara karşı duyduğu hayranlık ve saygı, şairi onların şiirlerine yönlendirir. İşte şair bu kazanımlarla sanat dünyasına girer. Böylece, güzel bulduğu şiirlere, hayranlık ve saygı duyduğu şairlere olan ilgi ile onların şiirlerine, aynı konu, aynı vezin, aynı kafiye ve redif ile şiirler yazar. Buna "nazire yazmak" veya "tanzîr etmek" ve "nazîre demek" adı verilir. Yazılan şiir de "nazire" olarak adlandırılır. Nazirenin çokluk şekli "nezấ'ir veya nezâyir = nazireler" olarak söylenir. Bu kelimeyi Türk edebiyatında ilk defa Fahreddin bin Mahmud Behcetü'l-Hadaik fî-Mev'izeti'lHalâik adlı eserinde kullanmıştır. Fahreddin bin Mahmud eserinde yer verdiği koşuk adı ile bilinen manzumeler için "ve benden dilediler kim bunlarun dilince bu fen içre bir kitâb eyleyem, nükte ve nezâyir birle 
söyleyem kim bularun dilegi kabul ola" demektedir (Koç 2011: 159-172). Nazireyi yapan şair de "nazîre-gû" veya "nazîre-perdâz" olarak anılır. Ancak ikinci şiiri yazan şairin birinci şairi, genellikle söyleyiş, edâ ve konuda geçmesi istenir (Köksal 2006: 43,97). Böylece edebiyatta bir genişleme ve yarışma da başlamış olur. Hatta bunun da ötesinde belki bir atışma havası da ortaya çıkar. Atışmada bir yarış iddiası bulunduğuna göre aynı durum nazire için de geçerliliğini korur. Bir şair bazen kendi yazdığ şiirine de nazire yazabilir. Bu durum şairin şiirde ilerlemesi ve ele aldığ1 konuyu daha da ileri götürmesi ve genişletmesi demektir. Bunun yanında nazire yazan kimi şairler, hangi şairin şiirini tanzir ettiklerini, genellikle makta beytinde zikrederler. Bu da edebiyatımızda XVI. yüzylldan sonra görülmeye başlar.

Nazire türü yalnız gazel ve kasidelerde olmayıp diğer nazım şekillerinde de yazılmıştır(Köksal 2006: 21). Sıra ile mesnevi, müstezat ve musammat nazım şekilleri ile de nazireler yazılmıştır. Ancak gazel tarzının nazirede önemli bir yeri vardır. Bu bakımdan farklı nazım şekillerinde yazılan şiirlere gazel ile "cevab" veya "nazire" yazıldığını da belirtmek gerekir. Bunun zıddı da olabilir. Yerine göre bir gazelin kaside ile tanzir edildiği de vakidir. Ayrıca gazelin kıta ve murabba ile tanzir edildiği nazire mecmualarında pek çok örnekle ortaya konmuştur. Bu, gazel nazım şeklinin diğer şekillere göre daha kısa oluşundan veya sanatkârın keyfî davranışından kaynaklanmış olabilir. Ancak her şairin düşkün olduğu ve tabiatına uygun gelen bir nazım şeklinin varlığı da düşünülebilir. Kasideye kaside, gazele gazel, murabbaa murabba kısaca ilk şiir hangi nazım şekli ile yazılmışsa, ona nazire yazan şairin de aynı nazım şeklini kullanması nazirede bir şart gibi görünürse de karşılaşılan örnekler bunun aynen uygulanmadığını da göstermektedir.

Bundan başka olarak nazirede bazı durumlarda daha fazla serbestlik ve esnekliklerin de bulunduğunu belirtmek gerekir. Bu açıdan bakınca "model" veya "zeminşiire", yani ilk yazılan manzumeye kafiyesi ve redifi aynı olmayan nazirelere de rastlanmaktadır. Bu ilk nazire mecmuası olan ve Ömer ibni Mezid tarafından yazılarak II. Murad'a sunulan Mecmu'atü'n-Nezâir'de yer alan zemin şiir ve nazire farklılığına yalnız bir şiirde rastlanmıştır. Halbuki daha sonra yazılan Eğirdirli Hacı Kemal'in Câmi'ü'n-Nezâir'i ileEdirneli Nazmi'nin Mecma'ü'n-Nezâir adlı eserinde 
böyle farklılıkların gitgide arttığını da belirtmemiz yerinde olacaktır. Bu durum yine on altıncı yüzyıl verimlerinden olan "Pervâne Beg Mecmuası"nda zemin veya model şiire benzemeyen ve nazire dışına çıkan çok sayıda şiirin varlığı ile daha da ileri götürülmüştür. Ancak nazire yazmanın şartlarını göz önüne alınca bu şekilde şaz, istisna yani kural dişı şiirlerin tartışmaya açık olduğunu da söylemeliyiz. Fakat bunların nazire mecmualarında yer alması, hatta şiirlere başlıklar konulurken "bahr-1 diğer" ve "kafiye-i mugayir-i redif-i û" gibi ibarelerin yazılması böyle şiirlerin de nazire dışında tutulamayacağını göstermektedir (Köksal 2006: 36).

Türk edebiyatında nazirede şart olan, vezin, kafiye, redif, konu ve eda bakımından, kısaca şekil ve muhteva yönü ile bulunması gereken benzerliklere on altıncı yüzyıldan sonra, yer yer uyulmadığı da bir gerçektir. Ancak bunlar yazılan nazirelere göre sınırlı sayıda şiirler olarak edebiyatımızda yer almıştır. Hatta yapılan tarifler göz önüne alınınca nazire ile ilgili kuralların yazılan eserlerde belirli şartları da ortaya koyduklarını dikkate almak gerekir. Ama her şiiri şekli ve içeriği uygun düşüyor diye nazire olarak değerlendirmek de doğru değildir. Çünkü kimi şiirler birbirine çok benzeseler de şairlerinin birbirinden haberi olmayabilir. Bu da sanatta bir rastlantı, bir tesadüf, bütün bunların da ötesinde, bir tevafuk demektir. Nazireye bakarken ve şiirleri bu açıdan değerlendirirken tevafuk olabileceğini de ayrıca hesaba katmamız gerekir.

Nazire yazma veya tanzir etmenin Türk edebiyatında bir genişlemeye de yol açtığını ayrıca zikretmeliyiz. "Nazire", bilindiği gibi "ce$v^{a b " ~ k e l i m e s i ~ i l e ~ d e ~ k a r s ̧ ı l a n m ı s ̧ t ı r . ~ C e v a b, ~ b i r ~ s ̧ i i r e ~ b a s ̧ k a ~ b i r ~ s ̧ a i r i n ~ y a z-~}$ dığı nazire şiirdir. Bu durumda şairlerin cevap vermeleri, hatta ortak bir konuda vezin ve kafiye yanında redif de beraber, birlikte şiir yazmaları durumu ile karşılaşırız. "Nazire"den başka olarak yazılan ortak şiirler her halde varlıklarını bu şekildeki manzumelerden almışlardır. Hal böyle olunca "şi'r-i müşterek" denilen bir beyit ve misraı bir şairin, diğer beyit veya mısraını başka bir şairin söylediği gazeller bunda en başta gelirler. Ayrıca Prof. Dr. Fatih Köksal'ın da belirttiği gibi, "gazel-i müşterek" denilen ve birden çok şairi olan gazellerden başka müselles, terbi, tahmis, taştir, tesdis, tesbi, tesmin, tetsi' ve ta'şir gibi nazım şekilleri de 
bir noktada varlıklarını nazireye borçludurlar. Zaten Türk edebiyatında bazı şairlerimiz şiirlerine nazire söylenemeyeceği iddiasında bulunurken, kimi şairlerimiz de edebiyatımızın büyük şairlerinin şiirlerine nazire söylemekle övünür ve hayranlık duyarken nazire edebiyatımız bu düşünceler arasında gelişmesine devam etmiş ve yirminci yüzyıla kadar gelmiştir. Buna paralel olarak yine on altıncı yüzyıldan sonra ortaya çıkan ve musammatlar içinde yer alan nazım şekilleri müsellesten ta'şire kadar, taştir de dâhil, varlıklarını müşterek ve ortak şiir yazma yönü ile bir başlangıç olan nazire türüne borçludurlar. Bu açıdan bakınca nazirenin Türk edebiyatında büyük bir işlevinin olduğunu ve şiir dünyamızı genişlettiğini de iddia edebiliriz. Bundan başka şairlerin karşılıklı şiir söylemeleri, müşâare ise; aynı zaman içinde söylenen şiirlerdir. Bu yönü ile müşâare, nazirenin yaşanan zamandaki canlı örneği olarak görülmektedir. İşte bütün bu uğraşlar nazirenin Türk şiirindeki tesir ve gücünü de göstermektedir. Bunun da ötesinde en mühimi şairler arasında bağ kuran, edebiyatımızı diri tutan, geçmişe götürdüğ̈̈ gibi, geleceğe açılan, tarih içinde şairlerin yetişmesine ve daha başka şiirlerin yazılmasına sebeb olan nazire edebiyatımız baştan sona edebiyat ve kültür dünyamızı dolaşan nefesler durumundadır.

Nazirenin şiirimizde ortaya çıkışını, tarihî gelişmesini ve çıkış durumunu göz önüne alırsak, Behcetü'l-Hada' $\imath k^{\prime} \tan$ öğrendiğimize göre Türk, Arap ve Fars edebiyatlarında XIII. yüzyıldan önce, "nazire"nin varlığı söz konusudur. Bu türün Anadolu'da başlayan Türk edebiyatında Yunus Emre (ö. 1320) ile ortaya çıtığını söylemek mümkündür. Yunus'un nazireleri Ahmed-i Yesevî́nin (ö. 1166) şiirlerine yazılmıştır. Ancak Yunus'tan önce bu türün ilk şairleri arasında yer vereceğimiz Türk şairi Hakîm Süleyman Ata'dır. Hakîm Süleyman Ata (ö. 1194) Ahmed-i Yesevî'nin hikmetlerine hikmetlerle karşılık vermiş, onun yolunu sadık bir öğrencisi olarak, devam ettirmiş ve şiirlerine nazireler söylemiştir (Sertkaya 2010 177-187). Şimdi Ahmed-i Yesevî'nin şu şiirine bakalım.

Behişt duzeh talaşur talaşmakda beyân bar

Duzeh aytur min artuk minde Fir'avn Hâmân bar

Behişt aytur ni dirsin sözni bilmey aytursin Sinde Fir'avn bar bolsa mende Yûsuf Ken'ân bar 
Duzeh aytur min artuk bahîl kullar minde bar Bahîllerni boynıda otlug zencir-keşân bar

Behişt aytur min artuk peygamberler minde bar Peygamberler aldıda Kevser hûr u gilmân bar

Duzeh aytur min artuk tersâ cühûd minde bar Cahûd tersâ aldıda türlüg azâb-sûzân bar

Behişt aytur min artuk mü'min kullar minde bar Mü'minlerning aldıda türlüg ni'met-elvân bar

Duzeh aytur min artuk zâlim kullar minde bar Zâlimlerge birürge zehr ü zakkûm çendân bar

Behişt aytur min artuk âlim kullar minde bar Âlimlerni könglide âyet hadîs Kur'ân bar

Duzeh aytur min artuk münâfıklar minde bar Münâfıklar boynıda otdın işkil-keşân bar Behişt aytur min artuk zâkir kullar minde bar Zâkirlerni könglide zikr ü fikr-i Sübhân bar

Duzeh aytur min artuk bî-namâzlar minde bar Bî-namazlar boynıda yılan bilen çıyan bar

Behişt aytur min artuk dîdâr körmek minde bar Dîdârın körsetürge Rahîm atlıg Rahmân bar

Duzeh anda dik turdı behişt özrini aydı

Hâce Ahmed ni bildi bildürgüçi Yezdân bar (Eraslan 1991: 328; Sertkaya 2010: 177-187)

Bu şiire Hakîm Süleyman Ata (Bakırgani) aşağıdaki nazire ile cevab vermiştir.

Uçmah tamug ögnüşür ögünmekde ma'nâ bar Tamug aytur men bay men mende Fir'avn Hâmân bar 
Uçtmah aytur yok sende cümle peygambar mende Sende Fir'avn bar bolsa mende Yûsuf Ken'ân bar

Tamug aytur men bay men dervişlerge çagır men Bahıllerge hâce men mende zâlim Avân bar

Uçtmah aytur yok sende cümle peygamber mende Muhammed-i Mustafâ Ömer Osman Ali bar Tamug aytur tahtımda tersâ cühûd mûg bende Her zâlimning yerinde toksan türlüg çayan bar Uçtmah aytur sende yok manga kelse ölüm yok Türlüg ni'metler anuk yüz ming hezâr elvân bar

Tamug munglaşa keldi uçtmahga özür kıldı Kul Süleymân ne bildi bildürgüçi Rahmân bar

Bu şiirin başka bir şekli de şöyledir:

Uçmah tamug ükneşür ükneşmekde niler bar Tamug aytur min bay min minde Fir'avn Hâmân bar

Uçmah aytur ni tir sin sözni bilmey sözler sin Sinde Fir'avn bar irse minde Yûsuf Ken'an bar Tamug aytur tahtımda tersâ cühûd mûg anda Her âlimning tenide toksan türlüg çıyan bar Uçmah aytur sözüm yok manga kilse ölüm yok Türlüg ni'metler anuk hezâr türlüg elvân bar Tamug aytur min bay min bahîlllerga çıgay min Dervişlerga çıgay min minde zâlim avân bar Uçmah aytur yok sinde cümle peygâmber minde Muhammedü'1-Mustafâ Bekr Ömer Ali Osman bar

Tamug manglaştı kildi uçmah hem özür koldı Kul Süleymân ni bildi bildürgüçi Cebbâr bar (Sertkaya 2010: 178- 
Her şeyden önce nazirenin Türk şiirine verdiği bir canlılık vardır ve bu canlılık asırlar boyu devam ederek Cumhuriyet devrine kadar gelmiştir. İşte nazire açısından bakınca konuda, vezinde, kafiye ve redifte benzerlik bulunan veya aynı olan kimi şiirler Yesevî'nin Anadolu yani Batı Türk edebiyatındaki takipçisi Yunus Emre'de görülür. Bu açıdan ele alınca Yunus'un pek çok şiiri Ahmed-i Yesevî̀ye nazire gibi görünür. Ancak Yesevî hikmetlerini, Doğu Türkçesi ile, Yunus ise Batı Türkçesinin ilk devresi olan Eski Anadolu Türkçesi ile yazmıştır. Tabii, dil bakımindan olan ayrılıkları ve zaman farkını bir yana bırakırsak, Yunus'un Ahmed-i Yesevî́yi ne kadar izlediğini ve ondan pek ayrılmadığını görmekte gecikmeyiz. Ahmed-i Yesevî́nin,

Hâlıkımnı izler min tün kün cihân içinde

Tört yanımdın yol indi kevn ü mekân içinde

Törtdin yitige yittim tokuznı güzer ittim

Ondın ikige kildim çerh-i Keyvân içinde

Üç yüz altmış su kiçtim tört yüz kırk tört tağ aştım

Vahdet şarâbın içtim tüştüm meydân içinde

Çünki tüştüm meydânga meydânnı tola kördüm

Yüz ming ârifi kördüm barça cevlân içinde

Gavvâs bahrıga kirdim vücûd şehrini kizdim

Dürni sadefde kördüm güherni kân içinde

Arş u Kürsî́ni yördüm Levh ü Kalem'ni kördüm

Vücûd şehrini kizdim aydım bu cân içinde

Cânnı kördüm cânânda 1şknı kördüm meydânda

Âşıklarnıng meydânı cümle bûstân içinde

İrni kördüm irgeştim istedügümni sordum

Barçası sinde didi kaldım hayrân içinde

Hayrân boluban kaldım bî-hûş boluban taldım

Özümni derdge saldım taptım dermân içinde

Miskîn Hâce Ahmed cânı hem güherdür hem kânı

Cümle anıng mekânı ol lâ-mekân içinde (Eraslan 1991: 304) 
hikmetine karşılık Yunus;

İstedügümi buldum eşkere cân içinde

Taşra isteyen kendü kendü nihân içinde

Kadîmdür hiç irılmaz ansuz kimse dirilmez

Adım adım yir ölçer hükmi revân içinde

Dutun diyü çağırur uğrı dahı çağırur

Bu ne acâib uğrı bu çağıran içinde

Siyâset meydânında galebeden bakan ol

Siyâset kendü olmış girmiş meydân içinde

Dartmış kudret kılıcın çalmış nefsün boynını

Nefsini depelemiş elleri kan içinde

Sayru olmış iniler Kur'ân ünini dinler

Kur'ân okıyan kendü kendü Kur'ân içinde

Bu tılısmı bağlayan cümle dilde söyleyen

Gör nice cevlân ider hırka pilân içinde

Dürlü dürlü imâret köşk ü saray yapan ol

Kara nikâb dutunmış girmiş külhan içinde

Başdan ayağa değin hakdur ki seni dutmış

Hak'dan ayru ne vardur kalma gümân içinde

Birisen birliğe gel ikiyi bırak elden

Bütün ma'nî bulasın sıdk u îmân içinde

Oruç namaz gusl u hac hicâbdur âşıklara

Âşık andan münezzeh hâlis heves içinde

Girdüm gönül şehrine taldum anun bahrına

Işk-1la gider-iken iz buldum cân içinde

Bu izümi izledüm sağum solum gözledüm

Çok acâibler gördüm yokdur cihân içinde 
Yûnus senün sözlerün ma'nîdür bilenlere

Söyleniser sözlerün devr-i zamân içinde (Timurtaş 1980: 163-165) şiirini yazmıştır. Yine Yesevî̀nin,

Işkıng kıldı şeydâ mini cümle âlem bildi mini

Kaygum sin sin tüni küni minge sin ok kirek sin

Ta'âlallâh zihî ma'nî sin yarattıng cism ü cânnı

Kullık kılsam tüni küni minge sin ok kirek sin

Közüm açdım sini kördüm kül köngülni singe birdim

Uruğlarım terkin kıldım minge sin ok kirek sin

Sözlesem min tilimde sin közlesem min közümde sin

Könglümde hem cânımda sin minge sin ok kirek sin

Fedâ bolsun singe cânım töker bolsang minim kanım

Min kulıng min sin sultânım minge sin ok kirek sin

Âlimlerge kitâb kirek sûfîlerge mescid kirek

Mecnûnlarga Leylâ kirek minge sin ok kirek sin

Gâfillerge dünyâ kirek âkillerge ukbâ kirek

Vâ'izlerge minber kirek minge sin ok kirek sin

Âlem barı uçmak bolsa cümle hûrlar karşu kilse

Allâh minge rûzî kılsa minge sin ok kirek sin

Uçmak kirem cevlân kılam ne hûrlarga nazar kılam

Anı munı min ne kılam minge sin ok kirek sin

Hâce Ahmeddür minim atım tüni küni yanar otum

İki cihânda ümîdim minge sin ok kirek sin (Eraslan 1991: 320)

şeklindeki hikmeti, yine Yunus'ta,

Işkun aldı benden beni bana seni gerek seni

Ben yanaram dün ü güni bana seni gerek seni

Ne varlığa sevinürem ne yoklığa yerinürem

Işkun-1la avunuram bana seni gerek seni 
Işkun âşıkları öldürür ışk denizine taldurur

Tecellî-y-ile toldurur bana seni gerek seni

Işkun şarâbından içem mecnûn olup tağa düşem

Sensin dün ü gün endîşem bana seni gerek seni

Sûfilere sohbet gerek ahîlere ahret gerek

Mecnûnlara leylî gerek bana seni gerek seni

Eger beni öldüreler külüm göğe savuralar

Toprağum anda çağura bana seni gerek seni

Yûnus-durur benüm adum gün geldükçe artar odum

İki cihânda maksûdum bana seni gerek seni (Timurtaş: 1980: 209-

şeklinde bir nazire ile karşılık bulur. Ahmed-i Yesevî'den gelen bu zemin veya model şiir, Yunus'tan başka şairler tarafından da tanzir edilmiştir. XIV. yüzyılın ikinci yarısı ile XV. asrın ilk çeyreğinde yaşayan Ahmedî (ö. 1413) de bu şiiri aşağıdaki şekilde tanzir etmiştir.

Cihândan ben usanmışam bana sini gerek sini

Kamulardan uşanmışam bana sini gerek sini

N'iderem bu ten ü cânı ya sensüz âb-1 hayvânı

Veyâhud dîn ü îmânı bana sini gerek sini

Gerekmez rûh-1la reyhân gerekmez hûr-1la vildân

Gerekmez ravza-i Rıdvân bana sini gerek sini

Gerekmez gönlüme selvet gerekmez rûhuma râhat

Gerekmez cânuma işret bana sini gerek sini

Gerekmez milket-i dünyâ gerekmez devlet-i ukbâ

Gerekmez Kevser ü Tûbâ bana sini gerek sini

İçüm sensüz cehennemdür yaşum-1la cihân nemdür

Benüm sensüz cihân nemdür bana sini gerek sini

Dilemez Ahmedî iy şeh ki anun ola mihr ü meh

Bu iki kevnde billâh bana sini gerek sini (Akdoğan 1979: II/171- 
Ahmedî kendisinden önceki şairlere nazire yazdı̆̆ gibi, devrinin şairlerine de yazar. Bunların başında Nesîmî ile Şeyhoğlu Mustafa gelmektedir. Bu durum özellikle Şeyhoğlu Mustafa ele alındığı zaman bir nevi atışma olarak da algılanabilir. Çünkü Ahmedî ve Ahmed-i Dâî Emir Süleyman'ın şiir meclislerinde bulunan şairlerdendir (Yavuz 2010: 631636). Ancak Ahmedî hemen her şairi kendinden öncekiler ve aynı zamanda yaşayanlar da dâhil tenkit eder. Bunların başında Şeyhoğlu Mustafa gelir. Şeyhoğlu Mustafa, saraya yakın bir şair olup Germiyan beylerinden Süleyman Şah'ın yanında yetişmiş, tercüme ve telif eserler bırakmış nazım ve nesir sahasında üstün bir sanatkârdır. Saraya yakınlığı sebebi ile Ahmedî'nin çekememezlik veya bir nevi hasedine uğramıştır. Ancak Hurşid-nâme'sinde gazel tarzında yazdığı şiirlerde Ahmedî ile nazire diyeceğimiz aynı vezin ve kafiyede manzumeleri ile dikkat çeker. Bu durum bir çeşit atışma da sayılabilir. Aşağıya aldığımız Nesîmî, Ahmedî ve Şeyhoğlu Mustafa'ya ait olan bu nazire şiirler on beşinci yüzyılın önde gelen şairlerinden Ahmet Paşa'yı da daha asrın başından müjdeler durumdadir.

Zülfüni anber-feşân itmek dilersin itmegil

Gâret-i dîn kasd-1 cân itmek dilersin itmegil

Burka' 1 tarh eylemişsin iy kamer yüzünden uş

Fitne-i âhir zamân itmek dilersin itmegil

Hatt u hâlün mantıku'tayr oldı ehl-i vahdete

Kuş dilin sen tercemân itmek dilersin itmegil

Çün ene'l-Hak'dan götürdi sûretün mâhı nikâb

Sen hakı niçün nihân itmek dilersin itmegil

Âşıka çok cevr idersin ahde kılmazsın vefâ

Adunı nâ-mihribân itmek dilersin itmegil

Sûretün genc-i hafîdür gösterürsin gözgüde

Âlem-i gaybı ayân itmek dilersin itmegil

Gamzeden Misrî kılıç virmişsin esrük Türkine

Kan bahâsuz bunça kan itmek dilersin itmegil 
Eyledi ışkun mahabbet tîrine kalkan beni Şimdi küllî bî-nişân itmek dilersin itmegil

Kirpügünden cân şikâr oklar düzermişsin meger

Kaşlarun yayın kemân itmek dilersin itmegil

Bâda virmişsin perîşân zülfüni dağıtmaga

Cânları bî-hânümân itmek dilersin itmegil

Şübhesüz bilün iki âlemde şâhum kimi yoh

Lâ-şebeh adın beyân itmek dilersin itmegil

Gitmek istersin gözümden dem-be-dem yaşum kimi

Cânumı tenden revân itmek dilersin itmegil

Lâ-tuharrik âyeti indi beyânun şânına

Ol beyânı sen beyân itmek dilersin itmegil

İy Nesîmî Hak'dan istersen götürmek perdeyi

Büt-peresti bî-gümân itmek dilersin itmegil (Ayan 1990: 213-214)

Nesîmî́nin bu şiirine Ahmedî nazire olarak şu şiiri yazmıştır.

Râzumı halka ayân itmek dilersin itmegil

Beni rüsvâ-yı cihân itmek dilersin itmegil

Mihnet-ile sa ferân itdün yüzümün rengini

Yaşumı dah'ergavân itmek dilersin itmegil

Gül yüzün gonca lebün nergis gözün idüp nihân

Nev bahârumı hazân itmek dilersin itmegil

Saçlarun bendinde bini idübenin mübtelâ

Gamzen-ile nâ-tüvân itmek dilersin itmegil

Bir kerânı olsa cefânun idileydi ihtimâl

Sen cefâyı bî-kerân itmek dilersin itmegil

Neyçün örtersin nikâb-1la bu zîbâ sûreti

Halkdan güni nihân itmek dilersin itmegil 
Ahmedî́nün kanını dökmekden assı yoh sana

Ol fakîre bir ziyân itmek dilersin itmegil (Akdoğan 1988: 162)

Ahmed-i Dâî de aynı şiire aşağıdaki nazire gazellerini yazmıştır. Ancakşairin iki gazel yazdığı dikkate alınırsa, aşağıya aldığımız bu gazellerden biri kendi şiirine nazire olarak da değerlendirilebilir.

Her nefes bin kasd-1 cân itmek dilersin itmegil

Bu cefâyı her zamân itmek dilersin itmegil

Bildük ol hûnî gözün kim cânumuz kasdındadur

N'ola nâ-hak yirde kan itmek dilersin itmegil

Âşıkı hicrân içinde zâri kıldun kılmagıl

Müdde îyi şâdumân itmek dilersin itmegil

Hüsnünün bâgı gülin her bir hasûda arz idüp

Nev bahârumı hazân itmek dilersin itmegil

Bülbül-i bâg-1 İremsin sahn-1 cennetdür yirün

Her budakda âşiyân itmek dilersin itmegil

Vasluna bin cân virürsem kıymeti olmaz henûz

Sen hod anı râyegân itmek dilersin itmegil

Dâ'iyâ vaslı hayâlin dutmagıl fikründe sen

Bu tasavvurdan ziyân itmek dilersin itmegil

$$
\text { / / / }
$$

Goncanun rengine al itmek dilersin itmegil

Bülbüli gülşende lâl itmek dilersin itmegil

İy yüzi bedr-i münevver kaşlarun aksi bile

Gökdeki bedri hilâl itmek dilersin itmegil

Kâmetün servi vü zülfün halkası ışkında uş

Bu elif kaddümi dâl itmek dilersin itmegil

Aklı kayd-1 çeşm ü leb kılmak dilersin kılmagıl

Rûhı sayd-ı zülf ü hâl itmek dilersin itmegil 
Bâdeyi sensüz içersem ben bana kıldum harâm

Sen sana kanum helâl itmek dilersin itmegil

Çün hayâl oldı vücûdum bu hayâl içre beni

Bir hayâl ender hayâl itmek dilersin itmegil

Dâ‘iyâ bilmez misin la'l-i Bedahşân kıymetin

Ol şeker-lebden su'âl itmek dilersin itmegil (Özmen 2001: I/125-

Nazire hemen her şairimizin başvurduğu bir yol ve deneyim olmuştur. Ancak şairlerimizin kendilerini daha da ileri götüren, sanat kabiliyetlerini yukarılara çeken kendilerinin olan ve özelliklerini veren şiirleri de vardır. Bu yönden bakınca her şairin şiir sanatında ayrı bir düğüm noktası olduğunu ve yazılan şiirlerin beğenilerek başka şairler tarafından tanzir edildiğini, böylece sanatta bir genişlemenin, bağlanıp çözülerek bir ilerlemenin bulunduğunu da görmemiz gerekir. Bu da şiire bir canlılık, yeni bir güç ve yeni bir hava getirmektedir. Ahmet Paşa'nın farklı bir nazım şekli ile Şeyhoğlu Mustafa'nın şiirlerine nazire yazdığını da görürüz.

Şeyhoğlu Mustafa, Ferahşâd ve Hurşid'in dilinden "gönül" redifli iki şiir yazmıştır. Bunlar birbirine nazire olarak karşımıza çıkmaktadır. Şâir birinci şiirini "Şi 'r-i Ferahşâd", ikinci şiirini de "Şi' r-i Hurşîd" başl1ğ1 ile cevap olarak yazmıştır. Birinci şiir,

Çün bulınmadı cihânda derdüne dermân gönül

Yiridür bu hasret ile ger alursan kan gönül

Işk bâzârında sana çünki hâsıldur ziyân

Bellü bil kim assı kılmaz nâle vü efgân gönül

Devr içinde ser-be-ser bîmâra tîmârın viren

Bir imâratlık sana virmedi iy vîrân gönül

İy dirîgâ bunca hecr ü zecr ü gam görmiş iken

Almadın dâdun felekden virisersin cân gönül 
Gerçi yârun vuslatı haccında bayram itmedün Yigrek oldur furkat içün olasın kurbân gönül

Lâcerem işkun belâsına mutî́ olmak gerek

Kimsenenün hükmine çün olmadun fermân gönül

Sen ki manzûrun felekdür niçe olursın helâk

İy gönül hayrân gönül olma gönül giryân gönül

şeklindedir. Hurşid'in dilinden söylediği ikinci şiir de aşağıdadır.

Minnet itme ger virürsen yârün içün cân gönül

Işka cânun terk idersen bulasın cânân gönül

İş ayakda kalmadı kim sonra başa gelmedi

Zâri kılma kalmayasın zâr u ser-gerdan gönül

Bu cefânun cevrin âhir irişesin lutfına

Karanulıkda bulınur Çeşme-i hayvân gönül

Hidmete bil bagladunsa irişesin devlete

Işka ger kul oldun ise olasın sultân gönül

Ger mahabbet Düldüline bindün ise sıdk ile

Gel berü meydân senündür kil bugün cevlân gönül

Kaynayup taşdukça çün dürler dökersin fevc fevc

Âferin esrâruna cûş eyle iy ummân gönül

Dünyede ad ise bârî sende hâsıldur murâd

İy gönül handân gönül olma gönül giryân gönül (Ayan 1969: 231-

Şeyhoğlu Mustafa'nın bu nazmlarına Ahmet Paşa da,

Gül yüzünde göreli zülf-i semen-sây gönül

Kuru sevdâda yeler bî-ser ü bî-pây gönül

Dimedüm mi sana tolaşma ana hây gönül

Vây gönül vây bu gönül vây gönül ey vây gönül 
Çîn-i zülfünden umar nâfe-i hoş-bûy-1 murâd

Bu hevâ yolına yıllarla yeler nite ki bâd

Ol dahı sencileyin itmedi ben hasteyi yâd

Vây gönül vây bu gönül vây gönül ey vây gönül

Felegün nûş iderem nîşini sâgarlar-1la

Togradı hâr-1 cefâ bagrumı hançerler-ile

Baş koşam dimez-idüm ben dahı dilberler-ile

Vây gönül vây bu gönül vây gönül ey vây gönül

Yârün itden çog uyar ardına agyâr dirîg

Bize yâr olmadı ol şûh-1 sitemkâr dirîg

Kıldı bir dilber-i hercâyiyi dildâr dirîg

Vây gönül vây bu gönül vây gönül ey vây gönül

Bizi hâk itdi hevâ yolına sevdâ n'idelüm

Pâymâl eyledi ol zülf-i semensâ n'idelüm

Kul idinmezdi güzeller bizi illâ n'idelüm

Vây gönül vây bu gönül vây gönül ey vây gönül

Dest-i kûtâhuma baş egmedi ol zülf-i dirâz

Oldı şekker lebine tûtî-i dil mahrem-i râz

Vâz geldüm ben eger gelse bu gönül dahı vâz

Vây gönül vây bu gönül vây gönül ey vây gönül

Dil dilerken yüzinün vaslını cândan dahı yig

Bir demin görür-iken iki cihândan dahı yig

Akdı bir serve dahı âb-ı revândan dahı yig

Vây gönül vây bu gönül vây gönül ey vây gönül

Ben dimezdüm ki hevâ yolına serbâz gelem

Ney-i 1şkıyla gamun çengine demsâz gelem

Dir-idüm 1şk kopuzın uşadup vâzgelem

Vây gönül vây bu gönül vây gönül ey vây gönül

Ahmed'em kim okınur nâmum-1la nâme-i 1şk

Germdür sözlerümün sûz-1la hengâme-i ışk

Dil elinden biçilüpdür boyuma câme-i 1şk

Vây gönül vây bu gönül vây gönül ey vây gönül (Tarlan 2005: 289- 
murabbaı ile cevap vermiştir. Ancak bu şiire yazılan nazireler bitmez. Yine Fatih devri şairlerinden Melihî de aşağıdaki murabbaını yazar. Bu durumda artık zemin veya model yahut da vasıta şiir Ahmet Paşa'nın şiiri olmuştur. Ancak hava, edâ ve söyleyiş yine Şeyhoğlu Mustafa'nın şiirinden gelmektedir.

Murabba

Seni bend itdi çün ol zülf-i semen-sây gönül Kılmadun dahı halâs olmak içün vây gönül İtdi sevdâ seni âlemlere rüsvây gönül Gönül ey vây gönül vây gönül ey vây gönül

İy hayâl-i ser-i zülfüne gönül mahrem-i râz Dest-i kûtâhuma baş egmedi ol zülf-i dırâz Virdi ol perdede iy mutrib-i uş̧̧âk-nüvâz Gönül ey vây gönül vây gönül ey vây gönül

Yâr-1 mahrem kanı arz itmege derd ü gam-ı dil Ki hemîn âh-1 sehergâh-durur hemdem-i dil Leb-i cân-bahşun eger virmez ise merhem-i dil Gönül ey vây gönül vây gönül ey vây gönül Zülfünün salalı hindûsı gönül boynına bend Cân u dil kim ola her lahza giriftâr-1 kemend Nice ola cigerüm âteş-i şevkunla sipend Gönül ey vây gönül vây gönül ey vây gönül Cânumı kıldı revân gamzen okı haste vü zâr Gönlümi turralarun eyledi bî-sabr u karâr Âh u efgân idüben çagıruram leyl ü nehâr Gönül ey vây gönül vây gönül ey vây gönül

Dil elinden nice bir kendümi âvâre kılam Tîg-i hasretle demidür cigeri pâre kılam Akl u dil oldı revân derdine ne çâre kılam Gönül ey vây gönül vây gönül ey vây gönül 
Gül yüzün gülşene hemdem oluban hâr ile hes

Bülbül-i hôş-nefesi oldı giriftâr-ı kafes

Nâle vü zâr-1la dirse bu Melîhî n'ola bes

Gönül ey vây gönül vây gönül ey vây gönül (Timurtaş 1974: 532)

Şeyhoğlu'nun Hurşid-nâme'de yer verdiği bunazım, ayrıca bir nazireler silsilesini de beraberinde getirmiştir. Önce Ahmet Paşa olmak üzere Melihî murabba nazım şeklinde nazireler yazmışlardır. Ayrıca Avnî mahlasını kullanan Fatih Sultan Mehmet ile Karamanlı Nizami muhammes olarak bu şiire nazireler yazmışlardır. Tabii sonra gelen şairlerin zemin şiir yerine Ahmet Paşa'nın murabbaını göz önüne almaları ve bu şiire, zemin şiir olarak, nazire yazmaları gerekir. Her ne şekilde olursa olsun Şeyhoğlu Mustafa'nın "nazım"1 zemin şiir olarak bu nazireler zincirinin başında yer almıştır. Şimdi de Fatih Sultan Mehmed'in şiirine bakalım:

Sevdün ol dilberi söz eslemedün vây gönül

Eyledün kendüzüni âleme rüsvây gönül

Sana cevr eylemede kılmaz o pervây gönül

Cevre sabr eyleyimezsin nideyin hây gönül

Gönül ey vây gönül vây gönül ey vây gönül

Çâk olan dest-i cefâ-y-ile girîbânundur İlişen hâr-1 gam u mihnete dâmânundur Dökilen yirlere belâ tîg1-y-1la kanundur Her dem ağıza gelen mihnet-ile cânundur Gönül ey vây gönül vây gönül ey vây gönül

Tâli'ün yüzi gülüp olmadı handân nideyin Yüregün derdine bulınmadı dermân nideyin Kasduna yâr çeker hançer-i bürrân nideyin Virisersin bu gam u mihnet-ile cân nideyin Gönül ey vây gönül vây gönül ey vây gönül

Işk-1 dildâr-1la niçe idesin nâle vü zâr Eyledün sabr u karârı bu hevâlarda nisâr Zülfi sevdâsı ider âlemi çün başuna dar Fâ'ide ne tutalum eyleyesin terk-i diyâr Gönül ey vây gönül vây gönül ey vây gönül 
Vasl-1 dilberle nasîb olmadı dil-şâd olmak

Dest-i cevr ile yıkılan dilün âbâd olmak

Dâm-1 gamdan dil ü cân bülbüli âzâd olmak

Niçeye dek işün efgân-1la feryâd olmak

Gönül ey vây gönül vây gönül ey vây gönül

Çünki dildâr niyâzun görüben nâz eyler

Nâleni işidicek şîveye âgâz eyler

Bezm-i gamda kaddüni çeng yüzün sâz eyler

Nâlişün perdesini Zühre'ye demsâz eyler

Gönül ey vây gönül vây gönül ey vây gönül

Bilmedüm derd-i dilün ölmek-imiş dermânı

Öleyin derd-ile tek görmeyeyin hicrânı

Mihnet ü derd ü gama olmagıçun erzânî

Avniyâ sencileyin mihnet ü gam-keş kanı

Gönül ey vây gönül vây gönül ey vây gönül (Doğan 2004: 158)

Yine aynı nazım şekli ile Karamanlı Nizâmî (ö. 1470) de şu nazireyi yazmıştır.

Düşeli 1şkuna ey ruhları bed-rây gönül

Oldı zülfün gibi âşüfte bu bed-rây gönül

Nice kim hâ didüm eslemeyüp hây gönül

Eyledi cümle cihâna beni rüsvây gönül

Gönül ey vây gönül vây gönül ey vây gönül

Geh deler hasretüne yüregümi şâne gibi

Geh yanar şem'-i ruhun şavkına pervâne gibi

Geh virür ârı yile âşık-1 dîvâne gibi

Geh döker gözlerümün yaşını dürdâne gibi

Gönül ey vây gönül vây gönül ey vây gönül

Hem-nefes olmaga sen hüsrev-i şîrîn-leb ile

Virmişem ârı yile nâm u nişânıyla bile

Dile düşmiş yalunuz ben degülüm ilden ile

Dil elinden niceler düşdi benüm gibi dile

Gönül ey vây gönül vây gönül ey vây gönül 
Tîr-i kaddümi kemân ideli ol hûr-nijâd

Şast-1 gamdan dil-i sevdâ-zede bula idi şâd

Dir idüm k'eyleyeyüm ben dahı dilberleri yâd

Dil elinden kime feryâd ideyin kim kıla dâd

Gönül ey vây gönül vây gönül ey vây gönül (İpekten 1974: 251252)

$\mathrm{Bu}$ nazire silsile halinde yukarıdaki şairlerden başka Hafî, Halîlî, Kemalpaşazâde (ö. 1534) ve Cafer Çelebi izlemiş, daha sonraki yüzyıllarda da devam ettirilerek yirminci yüzyıla kadar gelmiştir. Bu tekrar veya nakarat misrain her bendin sonunda yer alması ve söyleniş havasinda bir nevi acımayı ve merhameti de beraberinde getirmesi "gönül" kelimesinin "gözüm" kelimesi yanında başka şekillerde de söylenmesi ile bu murabba tam dokuz şekilde tekrarlanarak yüzyıllar boyu devam etmiştir (Tavukçu 2009: 1015-1020). Görüldüğü gibi başlangıçta gazel veya nazım, nazım şekilleri ile görülen bu şiir, Ahmet Paşa ve Melihî'de murabba şeklinde tanzir edilmiş, Fatih ve Karamanlı Nizamî tarafından ise cevap olarak muhammes nazım şeklinde ortaya konmuştur. Bu da şiirde bir genişleme ve şekil çokluğuna yol açmıştır.

Bundan başka olarak Ahmedî'nin şu meşhur gazeli de Ahmet Paşa tarafından tanzir edilmiştir. Bu gazel ayrıca Nesîmî ve Şeyhoğlu Mustafa'ya da bağlanmaktadır.

Tâ 1şkunı şâhâ varak-1 câna yazmışam

Levh-i gönülde adunı câna yazmışam

Sen hîç sormadun beni şîrîn budur ki ben

Şekker lebüne cânumı şükrâne yazmışam

Gönlüm evini ışkun içün dutmışam makâm

Genc-i nihânı gör ki ne vîrâna yazmışam

Hayretdeyem ki dudaguna la'l dimişem

Hacletdeyem ki dişüni dürdâne yazmışam

Bir kez cemâlüne nazar idem didüm şehâ

Mûsâ bigi tecellî odına yana yazmışam 
Susalıgumda la'lüni zikr eyledi dilüm

Âb-1 hayâtı Hızr bigi kana yazmışam

Yüzün sıfâtın Ahmedî imlâ ideliden

Gör kim ne hûb vech ile dîvâna yazmışam (Akdoğan 1979: 594-

Ahmet Paşa da bu gazeli aşağıdaki gibi tanzîr etmiştir:

Ser-nâme-i mahabbeti cânâna yazmışam

Hasret risâlesin varak-1 câna yazmışam

Nâlişlerini derd ile bîçâre bülbülün

Bâd-1 sabâ eliyle gülistâna yazmışam

Zülfün hikâyetini gönülde misâl idüp

Gam kıssasını levh-i perîşâna yazmışam

Resm itmişem gözümde hayâlüni gûyiyâ

Nakş-1 nigârı sâgar-1 mercâna yazmışam

Tâb-1 ruhunla sûzını yazarken Ahmed'ün

Şevkinden odlara düşüben yana yazmışam (Tarlan 2005: 312)

Yine Şeyhî́nin de, Ahmet Paşa tarafından tanzir edilmiş şiirleri vardır. Bunlar içinde Kerem Kasidesi'nin ayrı bir yerinin bulunduğunu belirtmek gerekir.

\section{Kaside}

Hurrem irdi bu kerâmetlü gün iy kân-1 kerem

Iyş u zevk it ki fedâdur yoluna cân-1 kerem

Kutlu dem bahtlu sâ'atdür ü ferhûnde zamân

Ki yine kullara teşrîf idiser hân-1 kerem

3. Câm-1 zer tutduğı 1yd ayı gibi devr-i felek

Ya'ni kim mevsim-i işretdür ü devrân-1 kerem

Kerem ehlin bu gice seyr cihânında görüp

Soraram bunlara kim n'oldı sehâ kanı kerem 
Didiler gel berü tâlib-i iksîr-i hayât

Gözle şol işiği kim toprağıdur kân-ı kerem

6. Dergeh-i şâh-1 atâ-pîşe vü hayr-endîşe

Germiyân memleketi mâliki sultân-ı kerem

Açılur ni'meti yağmurı-y-1la gülşen-i cûd

Bezenür kâmet-i servi-y-ile bûstân-1 kerem

Pâsbân saltanatı kasrına keyvân-ı felek

Sâyebân devleti dergâhına eyvân-ı kerem

9. Keremi ehline kısmet idicek Rabb-i kerîm

Gör kerâmet ki kirâm içre sever anı kerem

İy ki fazlun güheri mâye-i ummân-ı atâ

V'iy ki feyzün eseri dâne-i nîsân-ı kerem

Şeref-i zâtun-1la fahr ider evkât-1 şerîf

Kerem ü lutfun-1la hoş geçer âvân-1 kerem

12. Keffesinde dü cihân ni'metini az görür

Himmetin çünkü eline ala mîzân-1 kerem

Ne aceb ger yüz ura Hızr u Sikender kapuna

K'işiğinden akar uş çeşme-i hayvân-ı kerem

Gerçi Fir'avn ola düşmenleri kahritmek için

Yed-i beyzâdur elün hüccet ü bürhân-1 kerem

15. Ne aceb ger Karaman bulmasa âlemde emân

Çünkü yâr itdi sana devlet-i Osmân-ı Kerem

Boşalur kâse-i bahr u tükenür kîse-i kân

Bulımaz ni'met-i bî-haddüni pâyân-ı kerem

Çok işiğe yüz urur ille ki mahrûm döner

Yine kapunda bulur hürmeti mihmân-1 kerem

18. Lutf çevgânı-y-1la tapun urısardur tôp

Çünkü merdân-1 mürüvvet tuta meydân-1 kerem 
Şükr kıl fakrun-1la itme şikâyet Şeyhî

Derdüne şâh-1 kerîm eyleye dermân-1 kerem

Eller içre ne kadar k'anıla insâf u sehâ

Diller içre nice kim şen ola destân-1 kerem

21. Başlana adun ile nâme-i dîbâce-i cûd Yazila vasfun ile defter ü dîvân-1 kerem

Dâyim ola tapuna 1yd-1 safâ vakt-ı sa'id İşiğinden virile âb-1 sehâ nân-1 kerem (İsen vd. 1990: 58-59)

Şeyhî́nin bu kasidesine Ahmed Paşa aşağıdaki kasideleri nazire olarak yazmıştır (Tarlan 1992a: 68-69, 85-87). Ahmed Paşa'nın bu kasidesi, Fatih'in öfkesini çektiği iddiası üzerine yazıldı̆̆ı söylenirse de Ahmed Paşa Dîvânı'nı neşreden Prof. Dr. Ali Nihad Tarlan böyle bir hâdisenin vuku bulduğuna inanmamakta ve bu fikirlerini şöyle açıklamaktadır.

Tezkirelere nazaran bu tezvir ahlâkî bir mevzu üzerinde olmuştur. O sırada yazıp Padişaha takdim ettiği Kerem redifli kaside üzerine ahlâkî mesele muhtelif tezkirelerde ayrı ayrı hâdiseler şeklinde hikâye edilmiştir. Ve her biri Ahmed Paşa'nın bir beytini hâdise ile izah mahiyetinde bir hüsn-i tâlil sanatı yapmış hissini veriyor. Hâdisenin idama kadar varan neticesine ve bunun Kerem kasidesindeki bir beyte istinat ettirilmesine de itimad etmek mümkün değildir. Fatih gibi kadirşinas, ilim ve şiire bu derece düşkün bir padişahın ilim, şiir, zekâ ve zarafet bakımından çok takdir ettiğ i bir vezirini sırf şahsî ahlâk bakımından bir anda öldürtmeğe kadar ileri gitmesi tasavour dahi edilemez. Kaldı ki bu hikâyeyi rivâyet hâlinde birbirinden alıp nakleden tezkire müellifleri Kerem Kasidesi'ni lâyıkı ile tedkik etmemişlerdir. Bu kaside mâhiyetini bilmediğimiz bir sebeple ancak teveccüh ve alâkayı kaybeden bir insanın onu tekrar kazanmak için yazdiğı bir kasidedir. Yoksa ölüm korkusu içinde yazılmış bir kaside tamamen ayr bir mâhiyet arzeder. Gerek Fatih ve Ahmed Paşa'nın şahsiyetleri, gerek Kerem kasidesinin ruh ve üslûbu, böyle bir hâdisenin vukuuna ihtimal verdirmiyor. Lâkin muhakkak Padişah ile veziri arasında mâhiyeti mechûl bir hâdise cereyan etmiş ve neticesinde Ahmed Paşa gözden düşerek saraydan uzaklaştırulmıştır. Bursa'da Ahmed Paşa Muradiye ve ilâveten Emir Sultan vakıflarını bir müddet idare etmiş ve oradan mirlivaklıkla Sultanönü, Ankara ve Tire'ye 
tayin edilmiştir. Bayezid deorinde Padişahın iltifatına mazhar olarak Asşı Çelebi tezkiresine göre, pâye-i vezaretle; Bursa'ya vali olmuş ve orada 602/1496-97 tarihinde vefat ederek Muradiye Camii civarında kendi yaptırdığ medresenin yanındaki türbeye defnedilmiştir(Tarlan 1992a: 12).

"Kerem" kasidelerini ilk defa yayımlayan ve günümüz Türkçesi ile veren Hikmet İlaydın ise bu konu ile ilgili olarak; "Şeyhînnin düşünceli hassasiyetine, sakin ve ölçülü mısralarına karşılık Ahmed Paşa'nın gazellerinde tabiat ve insan güzelliklerinin içli ve atılgan bir iştiyakla ifade edildiğini hemen sezeriz. Bu bakımdan, Âşı Paşazade'nin ondan bahsederken söylediği: "mahbubların âh gözü ve kaşı ve zülfü ve benleri deyü deyü gitti!" sözlerine hak vermek gerekir. Nitekim günün birinde Padişahın gözdelerinden birine za'f göstermesi, başına büyük işler açmış, kendisi önce hapsedilmiş, ancak "kerem" redifli kasideleri sayesinde, belki korkunç bir âkıbetten kurtularak, Bursa'ya, Sultanönüne, Tire'ye, Ankara'ya, sonra gene Bursa'ya türlü memurluklarla gönderilmiş, fakat her şeye rağmen, divanın tertiplemesini bizzat isteyen II. Bayezîd devrinde bile, bir kere daha Osmanlı sarayına yaklaşamamıştı.

Sarayın kapıcılar odasında mahpusken yazdığı söylenen Kerem kasideleri iki tanedir. Bunlardan bilhasa birincisi tanınmıştır. Şair, 50 beyti geçen bu şiirde padişaha hitabetmektedir. Aşă̆ı yukarı 30 beyit tutan ikinci kaside, herhalde Padişah huzurunda hatırı olan bir vezire hitaben söylenmiştir. Bu zat, ihtimal ki, şaire karşı hususî bir teveccüh beslediği bilinen Sadrazam Mahmud Paşa'dır" demektedir (İlaydın 1956: 1-18; Tarlan 1992a: 12).

\section{Kaside}

I

Ey muhît-i keremin katresi ummân-1 kerem

Bâğ-1 cûd ebr-i kefinden dolu bârân-1 kerem

Matla-'1 subh-1 zafer mihr-i zekâ ebr-i hayâ

Felek-i izz ü alâ dâver-i devrân-1 kerem

3. Tâc-bahş-1 ser-i sultân-1 salâtîn-i cihân Zînet-i taht u nigîn Hazret-i Sultân-1 kerem Zıll-1 Hak Şâh Muhammed ki işiği göğünün Kem-terîn 1lduzı olur meh-i tâbân-1 kerem 
Ayağ1 toprağıdur cevher-i iksîr-i hayât Âsitânı tozıdur sürme-i a'yân-ı kerem

6. Açılur hulkı nesîmiyle gül-i gülşen-i cûd Bezenür lutfı zülâliyle gülistân-ı kerem

Bahr-1 Ahzar ne-durur kulzüm-i cûdunda habâb Katre-i feyzi nedür ebr-i dür-efşân-1 kerem

Bî-kıyâs olalı ihsânlarun iy hüccet-i cûd Kâtı' oldı cedel-i hasmını bürhân-ı kerem

9. Kefi bir demde nisâr itdüği gencün öşrin Haşre dek vezn idemez keffe-i mîzân-1 kerem

Ne melek-hûy meliksin dem-i lutfun ile Kevseri cûd akıdur ravza-ı Rıdvân-1 kerem Ne kerâmet kodı Hak zât-ı kerîmünde k'olur Ayağun basduğ 1 yir Çeşme-i Hayvân-1 kerem

12. Bulmasa nâm-1 şerîfünle şeref nâme-i cûd Ebter olaydı kamu defter ü dîvân-ı kerem Gün gibi saltanatun topı göğe ağsa ne tan Sana sunıldı bu meydânda çü çevgân-ı kerem Bahr-1 cûdun nice şerh ola k'anun reşhasıdur Hâsıl-1 kân-1 sehâ mâye-i ummân-ı kerem

15. Saltanat hil'atini kaddüne hayyât-1 felek Râst biçmese açılmazdı girîbân-ı kerem Ne kadar zer var ise dest-i zer-efşânun ile Harf-i zer gibi perâkendedür iy kân-ı kerem

Sîm sûretde sitem şekline yazıldugıçun Dağıdursın anı düşman gibi iy hân-ı kerem

18. Gök tenûrunda kuru kurs okınur mihr ile mâh Hân-1 lutfunla firâvân olalı nân-1 kerem 
Kâse-i hirs doyar sofra-i ihsânundan

Dest-i in'amun ile âm olalı hân-1 kerem

Mihr-i cûdun çemen-i lûtfa zer-efşân olalı

Gülşen-i dehri bezer nergîs-i bostân-1 kerem

21. Bûy-i hulkundan urur müşg gibi dem ki tutar Hôş revâhıyla cihân bağını reyhân-ı kerem Ahmed'ün gam makası kesdi dilin şem' gibi Sana rûşen diyemez hâlini sultân-1 kerem Sen Süleymânı ne dille öge bir mûr-ı za îff Getüre nutka meger lûtfun ile anı kerem

24. Husrevâ pâreledi cevr eli sabrum yakasın Dest-gîr olsa demidür bana dâmân-ı kerem Midhatun bülbülini gam kafesinde koma kim Hayfdur tûtîye zehr iy şekeristân-1 kerem Ekremü'l-halksın iy vâsıta-i ıkd-ı kirâm Her le'îmün sözin işitme budur şân-1 kerem

27. Kul hatâ kılsa n'ola afv-i şehenşâh kanı Tutalım iki elüm kanda imiş kanı kerem Umarım cürmümi gark itmeğe rahmet suyına Mevc-i ihsânun ile cûş ide ummân-1 kerem Bir kara toprağum ihyâ-yi memât itmek için Yağsa cûdun bulıdından n'ola nîsân-ı kerem

30. Nice k'iklîm-i mürüvvetde geçe hükm-i vefâ Nice k'eyvân-ı atâda dura dîvân-ı kerem

Nice k'insân ola âlemde abîdü'l-ihsân

Nice kim ola cihân tâbi-i fermân-1 kerem

Dest-i ihsânun ile yapıla bünyâd-ı sehâ Pâye-i kadrün ile yücele eyvân-1 kerem 
33. Nice kim Ka'be müsâfirlerini lutf-1 İlâh

Rahmeti hânına her sâl ide mihmân-ı kerem

Iyd-1 ferhundene kurbân ide a'dânı felek

Sen ehibbâna buyur âb-1 sehâ nân-ı kerem

Ömr-i hasmun ire târîh gibi pâyâna

Nâmunı nâme-i ikbâl ide unvân-ı kerem

$$
\text { Kaside }
$$

II

Yine 1yd oldu bu gün erdi çü devrân-1 kerem

Zevk $u$ ayş it yine hurrem olup iy kân-1 kerem

Dest-i cûdunla senün âm olalı ihsânun

Kapuna geldi umarâb-1 sehâ nân-1 kerem

3. Cûdunun katresidür kulzüm-i zehhâr-1 necât

Lûtfunun zerresidür ebr-i dür-efşân-1 kerem

Nazar-1 merhametün cevher-i iksîr-i hayât

Âsitânun tozıdur mihr-i dırahşân-ı kerem

Yine cûdunla biter verd-i gülistân-1 atâ

Yine sözünle olur meyve-i bostân-1 kerem

6. Açılur hulkun ile bu gül-i gülzâr-1 kemâl

Salınur lütfun ile yine bu atşân-1 kerem

Tûtî-i nutkuna lâyık şekeristân-ı makâl Bülbüli tab'una lâyık bu gülistân-1 kerem

İlmün ile okınur nüsha-i devrân-ı ulûm Adlün ile yazılur defter ü dîvân-ı kerem

9. Olmaya zât-1 şerîfün gibi bir cism-i latîf Gelmeye rûh-1 azîzün gibi bir kân-1 kerem

Ya'ni kim Âsaf-1 devrân mu'in-i fuzalâ K'ayağı toprağıdur sürme-i a'yân-1 kerem 
Matla'-1 şems-i hayâ mecmâ-1 envâr-1 atâ

Menba'-1 cûd u sehâ mâye-i ummân-ı kerem

12. Merkez-i sıdk u safâ dâ'ire-i nokta-i cûd Kâtı'-i hıdk u hased hüccet-i burhân-ı kerem

Zulmet-i fakrun içinde kalana göstere yol Matla'ından doğıcak bu meh-i tâbân-ı kerem

Ne Mesihâ-dem olursın ki dem-i lûtfun ile Kevser-i cân akıdur ravza-i Rıdvân-1 kerem

15. Yâ dehânunda senünçün ne kerâmet kodı Hak Teşne-i cûda olur Çeşme-i Hayvân-1 kerem Acebâ zât-ı kerîmün ne kerâmet kodı kim Basduğun yirler olur uçdan uca kân-1 kerem Bu felek yazmasa nüshandan eger nâmesini Yanlış olaydı kamu defter ü dîvân-1 kerem

18. Sana biçdi yine bir hil 'ati hayyât-ı cihân Kim anun dâmeni cûd oldı girîbân-1 kerem Bahr-i cûdunda atâ zevrakına yelken urup Bâd-1 lutfunla bugün gezdürür uş anı kerem N'ola gülzâr ola tab'um bite mehdin güli kim ? Ebr-i cûdunla yağar çün bana nisân-1 kerem

21. Şem-veş bezm-i kemâlünde yanar rişte-i dil N'ola rûşen dir isem medhüni sultân-1 kerem Kullaruz hâlümüz anlatmaya geldük kapuya İntizâruz ki icâzet vire sultân-ı kerem

Husrevâ pâdişehâ cûdunı dil şerh idemez Gerçi medhünle dolar defter ü dîvân-ı kerem

24. Âstîn-i keremünden pür olur dâmen-i çarh Âsitânında açıldukça girîbân-ı kerem 
Dürr ü gevher saçılur katre-i bârân yirine

Çünkü cûdun buludından yağa nisân-ı kerem

Kimyâ oldı kamu ehl-i sehânın nazarı

Olalı hâk-i derün sürme-i a'yân-ı kerem

27. Himmetün haylı sehâ mülküne kıldıkça nüzûl Çünkü her gûşe-i haymen ola meydân-1 kerem

Niçün iflâsum ola mûcib-i taklîl-i atâ

Niçin ihlâsum ola bâ'is-i hirmân-1 kerem

Ne revâdır ki cihân lutfuna gark olmış iken

Kapu kapu dolanam bulamayam nân-1 kerem

30. Nice bir gülmeye bu gonca-i gülzâr-i ümîd Bezenürken dem-i lûtfunla gülistân-1 kerem

Su batırmaz utanur kendü mürebbâlarını Beni niçün batıra gussaya ummân-1 kerem Beni hâr eyleme çün izzeti sen vermiş idin Lûtfuna olma perîşân ki budur şân-1 kerem

33. Hâric-i merkez ü hadd oldu çü üftâdeliğüm Demidür merhamet it var ise imkân-ı kerem

Ne kerem ola ki mağlûb edine anı günâh Ne güneh var ki zebûn eylemez anı kerem Tutmışuz çünkü hacâlet yüzine özr eteğin Ayb-pûş olsa ba'îd olmaya dâmân-1 kerem

36. Âmdır lûtfun eger bizde liyâkat yok ise Layık it lûtfun ile lûtfuna iy kân-1 kerem

Nola ger yâd edesin Ahmed'i bir lutfun ile Gerçi lâyık değülim sana budur şân-1 kerem

Ehl-i fazlun bilinür kadri senün kapunda Hazretün alsa eline yine mîzân-1 kerem 
39. Şeker-i midhatunun tûtîsi çok gerçi şehâ Görme her tûtîyi bir iy şekeristân-1 kerem

Şeref adunla bula nâme-i ikbâl ü atâ

Cûdun ile yazıla defter ü dîvân-ı kerem

Yir ü gök medhün okısun sen otur devlet ile

Âsumân tahtun ola menzilün eyvân-1 kerem

Ahmed Paşa'nın Fatih'e yazdığı bu kasideden sonra, Cem Sultan da Sultan II. Bayezid'e Kerem Kasidesi yazar ve bu şiir ile bazı isteklerde bulunur. Ayrıca Cem Sultan'ın kasidesine bu yönden bakınca büyük bir af dileğinin bulunduğunu görmekte gecikmeyiz. Cem'in yalvarmalara da yer veren bu kasidesi aşağıdaki şekildedir. Cem "kerem" kelimesine sarıldıkça sarılan, meded uman, suçunu bilen, yalvarıp af dileyen bir şairdir. Ancak ağabeyi ve sultan olan II. Bayezid onun buisteğini cevapsız bırakmıştır.

\section{Kerem Kasidesi}

İy sicill-i şiyemün matla' 1 dîvân-1 kerem

Nâm-1 cûdunla bulur zîneti ‘ünvân-1 kerem

Mefhar-1 mülk-i safâ mazhar-1 envâr-1 Hudâ

Mesned-i taht-1 vefâ dâver-i devrân-1 kerem

3. Zînet-i tâc u nigîn ü şeref-i millet ü dîn Husrev-i rûy-1 zemîn hazret-i sultân-1 kerem

Hükmi efgendesidür Rüstem-i destân-1 cihân İşigi bendesidür Husrev-i hakan-1 kerem

Bir nazarda kara topragı zer-i hâlis ider Olalı hâk-i rehi sürme-i a'yân-ı kerem

6. Gonca yâkût ola vü bergi zümürrüd güli la‘l Ebr-i lutfı döke ger gülşene bârân-1 kerem

Mihr-i lutfında degül zerrece envâr-1 vefâ Yem-i cûdında degül katrece 'ummân-1 kerem 
Güli âfâka virür bûy-1 vefâ neşv ü nemâ Perveriş bulalı lutfıyla gülistân-ı kerem

9. Keffi bir demde nisâr eyledügin eyleyimez Haşre dek dür döke ger ebr-i dür-efşân-1 kerem

La'1 ü yâkût-1la pür ola sadef dür yirine Himmet-i ebri eger yagdura bârân-1 kerem

Cân meşâmına irür bûy-1 safâ-yı ebedî Bâğ-1 lutfında bitelden berü reyhân-1 kerem

12. Halk-1 'âlem kamu hayrân ola bir cilvesine Kılsa tâvus bigi himmeti cevelân-ı kerem Mihr-i cûdından alup zerrece terbiyet-i lutf La'l yirine güher virdi Bedahşân-1 kerem Himmeti havzı kerem nehrini icrâ ideli Oldı dûlâb-1 felek ol suda gerdân-1 kerem

15. Nice Sultân-1 Ferîdûn-fer ü Dârâ-râsın Ki senün şânunâdur nass-1la bürhân-1 kerem Himmetün Kevseridür 'ayn-1 sehâ kim utanup Oldı zulmetde nihân Çeşme-i Hayvân-1 kerem İns ü cin cümle budur diye Süleymân-1 zemân Her kaçan kim kurıla karşuna dîvân-ı kerem

18. Devletün dârı cidârında düşen zerrece yok Haşre dek zeyn ide ger ravza-i Rıdvân-1 kerem Çal safâ topını meydân-ı mürüvvetde şehâ Çünki Hak sundı senün destüne çevgân-ı kerem Meh-i cûdun tutalı evc-i sa'adetde şeref Kem-terîn zerresidür mihr-i dırahşân-1 kerem

21. Deste-keş oldı çü bâzûna şehâ kavs-i murâd Ol kemânun yaraşur kim ola kurbânı kerem 
Key yaraşur sana bu cübbe-i devlet çün anun

Dâmeni lutf $u$ vefâ oldı girîbânı kerem

Bî-bahâ oldı 'akîk-i Yemen-i cûd u 'atâ

Bahr-1 lutfunda bitelden berü mercân-1 kerem

24. Ekrem-i zübde-i erbâb-1 kirâm olalı sen

Gören eydür ki hemân tapuna erzânî kerem

Feyz-i cûdûnla-durur zînet-i eyyâm-1 vefâ

Lutfun in'âmı ile zeyn olur avân-1 kerem

Âferîniş bulalı kâlıb-1 ervâh-ı safâ

Bulmadı zât-1 şerîfün gibi bir cân-1 kerem

27. Ne kerâmetlü yaratmış seni ol Hayy u 'Alîm

Ki senün cûduna bulınmadı pâyân-ı kerem

Âb-1 lutf-1la yolun sulayalı çeşm-i vefâ

Oldı cârûb işigün hâkine müjgân-1 kerem

Çemen-i lutfunı pür eyledi âvâze-i cûd

Mesken idelden anı murg-1 hoş-elhân-1 kerem

30. Feyz-i zer 'âleme dâ'im işigünden dökilür

'Ayn-1 zerakıdalı her yana iy hân-ı kerem

Mâl sûretde emel harfi-y-ile yazılalı

Dest-i cûdun tagıdur her yana iy hân-ı kerem

Külçe-i mihr ü mehi az göre bir mûr-1 za'îf

Sofra-i lutfun-1la 'âmm ola ger hân-1 kerem

33. Dilini deldi Cem'ün tîg-i cefâ hâme bigi

Nâme takrîr idemez hâlini sultân-1 kerem

Ben ne dille seni vasf eyleyem iy zıll-i Hudâ

Hâk kimdür ki seni medh ide iy kân-1 kerem

Lîk bî-vâsita hâlüm sana 'arz eylemege

Bu redîfi bana 'arz eyledi hullân-1 kerem 
36. Husrevâ dinle bu ben mûr-1 za'îfün hâlin Çünki sensin bu zemân içre Süleymân-1 kerem Mezra'-1 bahtumı dün biçer iken dâs-ı emel Ugrayu geldi benüm üstüme dihkân-1 kerem

Didi her kim ki hatâ tohmın eker sencileyin Olısar hirmeninün hâsılı hirmân-1 kerem

39. Nemek-i lutfun-1la bulmış iken lezzeti cân Bilmedüm gözlerüme tursa n'ola nân-1 kerem Yine yüz urmaga geldüm kapuna haclet ile 'Aybumı yüzüme urma ki budur şân-1 kerem Peyk-i zî-sıdkumı kapuna revân eyledüm uş Ger icâzet vire dergâhuna derbân-1 kerem

42. Sûziş-i hâlümi şol resme beyân ide sana Der ü dîvâr dahı aglaya kim kanı kerem Söyünür bâd-1 cefâ-y-1la şehâ şem'-i hayât Perde-gîr olmaz ise ger ana dâmân-ı kerem Ölürem zehr-i gam-1 dehr-ile ben haste garîb Ger dirîg eyleye tiryâkini Lokmân-1 kerem 45. Şeb-i hicrânda kaçan yol bula güm-râh gönül Reh-nümûn olmaz ise meş'ale-gerdân-1 kerem Nûh-1 lutfûn eger irgürmeye keştî-i necât Gark ider bahr-1 belâya beni tûfân-ı kerem Çünki evvel keremün âbına kandurmış-ıdun Husrevâ sonra yine olma peşîmân-1 kerem

48. Katre-i cûdunı çok görme bu ben teşne-dile Mevc-i lutfunda 'ayân oldı çü 'ummân-ı kerem Künc-i hüzn içre neden dil kala Ya'kûb misâl Yûsuf-ı lutfuna cây oldı çü Ke'nân-1 kerem 
Umaram meyve-i lutfunla bulam lezzet-i cân Gönül eşçârı çü 'arz eyledi agsân-ı kerem

51. Niçe bir bâr-1 belâ vire bu eşçâr-1 ümîd Âb-1 lutfunla ola tâze çü büstân-1 kerem

Çünkü evvelde tamâm eylemiş-idün keremi Umaram sonra dahı olmaya noksan-1 kerem

Lutfunun dâr-1 şifâsında bulınur çü devâ Umaram kim erişe derdüme dermân-1 kerem

54. Defter-i cürmüme bakma benüm iy kân-1 'atâ Kısas-1 cûduna zammoldı çü destân-1 kerem

Müşterîyem dil ü cândan k'ola bâzârı safâ Çârsû-yı ni'amun açalı dükkân-ı kerem

Keremün cümle giriftârı halâs eyler iken Ne revâdur bana lâyık göre zindânı kerem

57. Gerçi yüzüm karadur nâme-i a'mâl gibi Umaram kim yuya lutfun suyıla anı kerem Hâr-1 gamdan niçe bir gonce gibi kan yudayın Dem-i lutfunla gülerken gül-i handân-1 kerem

Keremün hil'atıla fahr-ider-iken dü-cihân Ben revâ mı ki kalam arada 'uryân-ı kerem

60. Ne revâdur ki bana dehr şuna zehr-i firâk 'Âleme cân virür iken şekeristân-ı kerem Bî-sitâre yaraşur mı ki gezem âlemi ben Zeyn iken necm-i 'atân-1la şeb-istân-1 kerem

Ne keremdür ki ola mûceb-i tecdîd-i güneh Ne günehdür ki ola ba'is-i hirmân-1 kerem

63. Dest ü pâ-beste vü dil-haste vü ser-geşte vü zâr Der-i dîvânuna geldüm yine sultân-ı kerem 
Tîg-i hışm elde vü boynumda kefen ortada baş Tâbi'em her ne ki emr eylese fermân-1 kerem 'Âmdur lutf-1 amîmün ko günâhumu benüm Merhamet vaktı-durur var-1sa imkân-1 kerem 66. Gerçi kim cürm ü hatâdur işümüz n'oldı 'atâ Gerçi kim iki elüm kanda velî kanı kerem

Gel du'â başla yiter söyle şikâyet sözini Çünki vâkıf-durur ahvâlüne ol hân-1 kerem

Niçe kim bâg-1 safâ içre nem-i şeb-nem-i cûd Gonca-i lutf-1 lebine ura dendân-1 kerem

69. Niçe kim zinde k1la 'âlemi ervâh-1 safâ Niçe kim bende kıla lutf-1la insânı kerem

Niçe kim mülk-i safâ içre geçe hükm-i vefâ Niçe kim arada meşhûr ola ihsân-1 kerem

Niçe k'eyvân-1 safâda kurıla hayme-i cûd Niçe kim nat'-1 vefâ döşeye meydân-1 kerem

72. Niçe kim ola 'atâ defter-i dîbâce-i cûd Niçe kim ola vefâ nâme-i 'ünvân-ı kerem Hak mezîd eyleye tomâre-i ömrüni senün Zeyn ola nâmun ile defter ü dîvân-ı kerem

Devletün dârını ma'mûr ide mi'mâr-ı ezel Şöyle kim yüz süre işigüne erkân-1 kerem (Ersoylu 1989: 24-29)

Kerem kasideleri zinciri daha bitmemiştir. Necâtî de aşağıdaki kasideyi nazire olarak yazmıştır (Tarlan 1992b: 89-91). 
Kaside

Hamdülillah kim irişdi yine devrân-1 kerem

Beht ile çıktı şeref tahtına sultân-ı kerem

Yegi şeh-zâdelerün Hazret-i Sultân Mahmûd

Begi âzâdelerün zill-i Hudâ hân-ı kerem

3. Yazılur nâm-1 hümâyûnı ile defter-i cûd

Okınur hulk-1 şerîfi ile destân-ı kerem

Tab'una cûd u sehâ şöyle yakışdı ki gören

Dise olur ki atâ dînidür îmân-ı kerem

Dir dimez Hâtem-i Tayy defterini dürdi cihân

Şehriyâr adına okumalı dîvân-ı kerem

6. Zer ü yâkût bağışlar gülerek gül gibi

Habbezâ bağ-1 cihân içre gülistân-1 kerem

Meclisine nice gülşen dimesün her kişi

Her nefesde açılur gonca-i handân-ı kerem

Tâ huzûr ile ide halk ferâgat hâbın

Yağdurur ebr-i kefi âleme bârân-1 kerem

9. İşiğine yüz uranlar ebedî kalmak için

Silsile lutf-ı demâdemdür ü zindân kerem

İşiğinden ne aceb dirlik umarsa âlem

Ki kapun toprağıdur Çeşme-i Hayvân-1 kerem

Bahr acır kan iniler ebr-i bahârî ağlar

Meclisin devr edicek sâğar-1 handân-1 kerem

12. Göricek taht-1 şerefde seni Belkîs-1 cihân

Didi uş mühr-i sehâ ile Süleymân-ı kerem

Bir sarâyun beğisin devlet ile Şâhâ kim

Hâdimi cûd u sehâ ile Süleymân-ı kerem 
Gayrı şehler kereminden eger ihsân ideler Sen idersin bu cihân halkına ihsân-ı kerem

15. Nûr-1 re'yün var iken mihre ziyâ-bahş dime Her hasîse kerem it eyleme bühtân-1 kerem Halka gibi dolanur dâ'iresin halk-ı cihân Devletün sofrasına zeyn olalı hân-ı kerem Ger sitârem var ise halkası olam didi çarh İşiğinde yayıcak sofra-i ihsân-1 kerem

18. Husrevâ sen güneşün terbiyeti ile verir Bu kadar la'li vü bu denlü zeri kân-1 kerem Eğer olmazsa Şehâ ebr-i kefünden himmet Kanda bulurdı bu gevherleri ummân-ı kerem Döndi ol devr ki bin hüzn ile erbâb-1 kemâl Âhidüp dirler idi n'oldı sehâ kanı kerem

21. Uşda kapun felekinden gece gündüz lâmi` Meh-i tâbân-1 sehâ mihr-i dırahşân-1 kerem Nite kim encüm ile zeyn ola bu tâk-1 kebûd Zer-i ihsânun ile nakş ola eyvân-1 kerem

Dinle güftârunı lutfit ki Necâtî benden Bülbül-i bâğ-ı atâ oldı senâ-hân-1 kerem

24. Serverâ sarsar-1 gamdan söyinür câm-1 murâd Dest-gîr olmaz olursa ana dâmân-ı kerem Ben esîrün sitemi dehrden âzâd eyle Ben gedâya nazar it lutf ile sultân-1 kerem İtme bünyâd-1 cefâ âdet iken lutf u vefâ Eyleme meyl-i sitem var-iken imkân-ı kerem

27 Mücrim ü âsî isem lutf ile rahmet yaraşur Pâdişâhum çün olur afv-1 günâh şân-1 kerem 
Zerre kimdür ki sala hâtır-1 hûrşîde gubâr

Katreden telh ola mı bahr-i firâvân-1 kerem

Nice cûş itse deniz taşraya salmaz güheri

Sürme hışm ile kapudan beni ummân-ı kerem

30. Pâdişâhâ nice bir rûze-i fakr ile geçem

Iyd-1 işret günidür iy meh-i tâbân-1 kerem

Nice kim âlem ola 1yd-ı hümâyûn ile şâd

Nice kim âdem ola tâbi'-i fermân-ı kerem

Giceni kadr ü günün 1yd ide Sübhân-1 Kadîm

Görelim taht-1 şerefde seni Hakân-1 kerem

Bundan sonra da edebiyatımızda kerem kasideleri yazılmıştır. Resmî, Mehdî ve Ahmed-i Rıdvan'ın kasideleri ile kerem kasidesine yazılan nazireler devam etmiştir (Göre 2009: 919-957). Hatta XVII. yüzyıl şairlerinden Yâri de 41 beyitlik bir nazire yazmıştır (Karayazı 2012: 473475). Bundan başka olarak, Şeyhî'nin gazellerine başta Şah İsmail Hataŷ̂ olmak üzere diğer şairler tarafından nazireler de yazılmıştır. Şeyhî'nin aşağıdaki gazeline bakalım:

Gönül bende tapuçı cân senündür

Ne buyursan şehâ fermân senündür

Hatâ kuldan atâ şehden hemîşe

Mürüvvet kânısın ihsân senündür

Felekler müşterîdür gün yüzüne

Süregör iy kamer devrân senündür

Süvâr ol devlet atına melik-vâr

Sa'âdet topın ur meydân senündür

Susamışları iy Hızr-1 zamâne

Suvar kim Çeşme-i hayvân senündür

Bu gice cânumı kurbâna yazdum

Kabûl eyler isen mihmân senündür 
Kapuna geldi Şeyhî âciz ü hôr

Eger ayb ola ger noksân senündür (İsen vd. 1990: 127)

Şeyhî’nin bu gazeline Hatayî aşağıdaki şekilde cevap vermiştir:

Ne buyursan şehâ fermân senündür

Yolunda cân u baş kurbân senündür

Hatâ menden atâ senden eyâ dôst

Ki mürvet vaktıdur ihsân senündür

Susamış leblerün Hızr-1 zamâna

Suvargil Çeşme-yi hayvân senündür

Süvâr ol dövlet atına hemîşe

Sa'âdet topı hem çevgân senündür

Melekler müşterîdür gül yüzüne

Sür imdi iy kamer dövrân senündür

Ezelden cânumı kurbân virerdüm

Kabûl eyle şahâ fermân senündür

İşiğünde kulundur bu Hetâ'î

Nazar kıl hâlına heyrân senündür (Cavanşir vd. 2006: 369)

Yine devrin bir başka şairi olan ve XVI. yüzyıla bir güneş gibi doğan usta ve büyük şair Necâtî Beg şiirlerine nazireler yazılan, bu yönü ile dikkat çeken bir şairdir. Bunların başında Amasyalı şair Mihrî Hatun gelmektedir. Latifî́nin “gazellerinin çoğu merhum Necâtî̀ye nazire olarak söylenmiştir. Bundan kastı şiir seviyesi bakımından ona yetişmekti, ancak Necâtî bundan rahatsızlık duymakta idi" derken Mihri'ye hitâben,

İy benüm şi' rüme nazîre diyen

Çıkma râh-1 edebden eyle hazer

şeklinde bir tembihte de bulunmuş̧tur. Yapılan araştırmalar Mihrî́nin Necâtî Beg'in elli beş şiirini tanzîr ettiğini ortaya çıkarmıştır (Arslan 2009: 121-131). Edebiyatımızda önemli bir yeri olan, şairlerin yetişmele- 
rinde büyük rol oynayan, hatta dükkânını bir nevi şairler mahfili yapan böylece bir topluluğa tecrübeleriyle yol gösteren Balıkesirli Zâti de Necâtî Beg'e nazire yazan şairler arasında yer alır. Onun;

Şarâb-1 1şka ol sâkî öpül ömrüm kuçul ömrüm

Degüldür hûblık bâkî öpül ömrüm kuçul ömrüm

Dühûl it bezm-i rindâna sehergâhdan zarîfâne

Çeküp câm-1 mey-i bâkî öpül ömrüm kuçul ömrüm

Lebün dil derdine emdür tenün kâfûrı merhemdür

Dil-i pür derde ol yakı öpül ömrüm kuçul ömrüm

Hasûdı seg gibi sinlet rakîbi derd ile inlet

Müşerref eyle uşşâkı öpül ömrüm kuçul ömrüm

Çıkar lutf-1 vefâ adın yile varup tagılmadın

Gül-i ruhsârun evrâkı öpül ömrüm kuçul ömrüm

Hasedden düşmanı öldür ferahdan âşıkı güldür

Sevindür cümle uşşâkı öpül ömrüm kuçul ömrüm

Ne nâzük olur ol dilber görüp Zâtî ana diler

Cihânun cümle züvvâkı öpül ömrüm kuçul ömrüm (Tarlan 1970:

gazelini, Necâtî́nin aşağıdaki şiirine nazire yazdığını görürüz.

Bugün hüsnün zamânıdur öpül ömrüm kuçul cânum

Güzellik çünki fânîdür öpül ömrüm kuçul cânum

Öpülmekden çü kan olmaz kuçulmakdan ziyân olmaz

Güzellik câvidân olmaz öpül ömrüm kuçul cânum

Sarılmak bir hidâyetdür kuçulmak hoş sa'âdetdür

Bilürüz bûse âdetdür öpül ömrüm kuçul cânum

Geçer kalmaz zamândur bu güneş gibi ayândur bu

Vefâsı yok cihândur bu öpül ömrüm kuçul cânum

Bakup serv-i bülendüne nazar kıl kendü kendüne

Necâtî derdmendüne öpül ömrüm kuçul cânum (Tarlan 1992b: 
Ancak burada nazire şartlarından birinin yerine getirilmediğini veya değiştirildiğini de belirtmemiz gerekir. $\mathrm{O}$ da Necâtî́nin şiirine bakınca redif olarak kullanılan kelimelerin öpül ömrüm kuçul cânum şeklinde verilmesidir. Bu durum, Zâtî tarafından, öpül ömrüm kuçul ömrüm diye değiştirilmiştir. Diğer yandan her iki gazele baktığımız zaman musammat yönü ile de benzerliğin bulunduğunu söylemek lazımdır. Böyle bir şeklin nazire edebiyatında yer alması ve bilindiği kadarı ile bilinen ilk örnek olarak görülmesi dikkat çekici bir husustur. Araştırıldığı takdirde daha başka örneklere de rastlamak mümkündür. Bu hâl nazire bahsinde daha geniş toleransların da olabileceği kanaatini uyundırmaktadır. Her halde bu gazeller Türk şarkı edebiyatının da ilk sızıntıları olacaktır.

Necâtî, on beşinci yüzyılın son çeyreğinden itibaren bütün on altıncı yüzyıl da dâhil, on dokuzuncu yüzyıla kadar etkisini sürdüren ve şiirlerine pek çok nazire yazılan bir şair olmuştur. XVI. yüzyılın şairleri başta Sehî Beg, Fuzûlî olmak üzere, Bâkî'ye kadar pek çok şair onun şiirlerini tanzir etmiştir. Fuzûlî,

Hâsllum yoh ser-i kûyunda belâdan gayrı

Garazım yoh reh-i ışkunda fenâdan gayrı

Nây-1 bezm-i gamem iy âh ne bulsan yile vir

O da yanmış kuru cismümde hevâdan gayrı

Perde çek dîdeme hicrân güni iy kanlu yaşum

Ki gözüm görmeye ol mâh-likâdan gayrı

Yitdi bî-kesligüm ol gâyete kim çevremde

Kimse yoh çizgine girdâb-ı belâdan gayrı

Ne yanar kimse mana âteş-i dilden özge

Ne açar kimse kapum bâd-ı sabâdan gayrı

Bozma iy mevc gözüm yaşı habâbın ki bu seyl

Komadı hîç imâret bu binâdan gayrı

Bezm-i 1şk içre Fuzûlî nice âh eylemeyem

Ne temettü bulınur neyde sadâdan gayrı 
gazeli ile (Tarlan 1950: 160-161), Necâtî́nin aşağıda yer verdiğimiz, şiirine nazire yazmıştır (Tarlan 1963: 520-521).

Dime kim yârda yok cevr ü cefâdan gayrı

Ne dilersen bulınur mihr ü vefâdan gayrı

Beni aglan beni kim üstüme gelmez ölicek

Bir avuç toprak atar bâd-1 sabâdan gayrı

Elif-i kâmetün ile kaşuna râ diyeli

Gönlümi egleyimez kimse bu râdan gayrı

Hatt $u$ hâlün elemi yitmedi mi gönlüme kim

Çeke hicr âteşini bunca belâdan gayrı

Ne garaz eyleye uşşâk visâlün var iken

Ne murâd eyleye bîmâr devâdan gayrı

Dûd-1 âhum ne aceb göklere tutsa yüzini

Âşıkun kimisi var ola Hudâdan gayrı

Yüzine tutsa Necâtî ne aceb haclet elin

Nesi var yüze gelür dest-i du'âdan gayrı

Aynı gazele nazire yazan bir başka şair de, Âzerî Türkçesi ile yazan Seyyid Nigârî olmuştur. Ayrıca Bâkî (ö.1600) onun meşhur olan,

Çıkalı göklere âhum şereri döne döne

Yandı kandîl-i sipihrün ciğeri döne döne

Ayağı yir mi basar zülfüne berdâr olanun

Zevk u şevk ile virür cân u seri döne döne

Şâm-ı zülfünle gönül Mısrı harâb oldı diyü

Sana iletdi kebûter haberi döne döne

Sen durup raks idesin karşuna ben boynum eğem

İne zülfün kuça sen sîmberi döne döne

Ka'be olmasa kapun ay ile gün ley ü nehâr

Eylemezlerdi tavâf ol güzeri döne döne 
Sen olasın diyü yir yir asılup âyineler

Gelene gidene eyler nazarı döne döne

İy Necâtî yaraşur mutribi şeh meclisinün

Raks urup okıya bu şi'r-i teri döne döne (Tarlan 1963: 433-435)

gazeline cevap olarak,

Çıkar eflâke derûnum şereri döne döne

Dökilür hâke yaşum katreleri döne döne

Âşık-1 haste-dilün niteki fânûs-ı hayâl

Nâr-1 1şkunla yanupdur cigeri döne döne

3. Pister-i gamda gözüm giceler uyhu görimez

Eydürin subha degin nâleleri döne döne

Zevrak-âsâ gam-1 1şkunla yaşum girdâbı

Gark idüpdür sanemâ çeşm-i teri döne döne

İydgâhun göreyin inlesün ol dôlâb1

İle seyr itdürür ol sîmberi döne döne

6. Dîde-i encüme kühl olmag içün eflâke

Gird-bâd ile çıkar hâk-i deri döne döne

Tolaşaldan ruhı şem ine dil-i sergeşte

Yakdı pervâne-sıfat bâl ü peri döne döne

Katre-i eşkine öykindi diyü Bâkî́nün

Çarh-ı hakkâk yonupdur güheri döne döne

gazelini yazmıştır (Küçük 1994: 387). Necâtî'den gelen bir zemin şiir olan bu gazel yalnız Bâkî́nin tanziri ile kalmamış, başta III. Murad Han olmak üzere, daha sonraki asırlarda da dillerden düşmemiş ve on dokuzuncu yüzyılın büyük şairi Osman Şems'e kadar gelmiştir. Yine Necâtî'nin "hançer" redifli kasidesine Fuzûlî, Revânî, Üsküplü İshak Çelebi ve Kemalpaşazâde kaside; Mesîhî, Muhibbî, Bâkî, Gelibolulu Mustafa Âlî, Ulvî ve Osmanzâde Tâib de gazel nazım şeklinde nazireler 
yazmışlardır (Koncu 2010: 99-130). Ancak Edirneli şair Sâgarî ayrı bir yol tutmuş Necati Beg'in gazellerini değiştirmek ve hicve dönüştürmek yolu ile nakîzeler yazmıştır (Musali 209: 309). Bilindiği gibi nakîze, bir şiir esas alınarak onunla aynı vezin ve kafiyede, fakat anlamca zıt konuda olan ve bir nevi zemin şiire reddiyye olarak yazılan şiirlere denmektedir (Köksal 2006: 59).

XVIII. yüzyılın büyük şairi Şeyh Gâlib ise, şiiri ile övünürken şairlere meydan da okumuştur. O Hüsn ü Aşk adlı mesnevisini bitirirken Fahriyye-i Şâirâne başlı̆̆ını taşıyan kısmında (Doğan 2002: 402-404);

Tarz-1 selefe tekaddüm etdim

Bir başka lugat tekellüm etdim

Ben olmadım ol gürûha peyrev

Oymuş belî Gencevî́ye Hüsrev

Billâh bu özge mâcerâdır

Sen bakma ki defter-i belâdır

Zannetme ki şöyle böyle bir söz

Gel sen dahı söyle böyle bir söz

Erbâb-1 sühan tamâm ma'lûm

İşte kalem işte kişver-i Rûm

Gördün mü bu vâdî-i kemîni

Dîvân yolu sanma bu zemîni

Engüşt-i hatâ uzatma öyle

Beş beytine bir nazîre söyle

Az vaktda söyledimse anı

Nâpuhteligin degil nişânı

Gördük nice şâhlar gedâlar

Bir anda yapar anı babalar

Gencînede resm-i nev gözetdim

Ben açdım o genci ben tüketdim 
diyerek kendini ve eserini ortaya koymuştur. Gerçekten divan edebiyatımızın son büyük temsilcilerinden olan ve yeni Türk edebiyatı içinde bile pek çok şairi etkisi altında bırakan Gâlib Dede, şiirlerinde kültür yoğunluğu olan bir şairdir. Bu yönü ile o evinli başaklara benzer, şiiri dolu ve tok olduğu gibi övünmesi de yerindedir. Her şiire hata parmağ uzatılabilir, ancak Gâlib kendi şiirine böyle bir parmağın uzanmasını istemez. Yukarıda görüldüğü gibi yüksekten konuşur ve şairlere meydan okurken, şiirine nazire yazılmasını, fakat bunun zor bir iş olduğunu da söylemekden çekinmez.

Nazire yazma geleneği Türk edebiyatının her devri ve her bölgesinde karşımıza çıkmaktadır. On beşinci yüzyıl Çağatay Türkçesi edebiyatına bakınca aynı geleneğin Lütfi ile Ali Şir Nevâî arasında da bulunduğunu görürüz. Lütfî’nin,

Köktedür her dem figânım körgeli sin mâhnı

Da'va-yı mihrimga tanuk tartadur min âhnı

Sin kibi sultânı sivmek haddim irmestür velî

Bu belâlık ışk fark itmes gedâ vü şâhnı

Zülf ü ay yüzüng firâkında tümen hasret bile

Âh kim zâyi` kiçürdüm munça sâl u mâhnı

Dâne-i hâlıng temennâsıda iy gül hurmeni

Kıl nazar kim çehre-i zerdim yaşurdı kâhnı

Agzıngıznıng fikrini mundak ki kördüm âhirî

Başlagusıdur 'adem sarı min-i güm-râhnı

İşikingdür taht-ı devlet hâk-i pâyıng efserim

Tapmadı Cemşîd ü Efrîdûn bu kadr u câhnı

Kavma Lutfîni işikdin bay zekât-1 hüsn üçün

Kimdin itsün sin ganî barında şey'ullahnı (Karaağaç 1997: 245-255)

bu gazeline Ali Şir Nevâi de aşağıdaki gazel ile cevap veriyor. 
İstemem könglümni iylerde hayâl ol mâhnı

Kim tahayyül birle seyr iyler n'iter hem-râhnı

Könglüm ister ni tiler min barıng ey ay $\mathrm{u}$ kuyaş

Sizni köngli istemes ol kim tiler dil-hâhnı

Okı zahmın ten ara ol yüz hayâli yarıtur

Eyle kim Yûsuf cemâli rûşen itkey çâhnı

Cân u akl u hûşdın kiçkil diding kıldım kabûl

Terk itealman n'itey nezzâre-i geh-gâhnı

Garka boldı nâtüvân cismim sirkişkim bahrıda

Gerçi su niçe tireng bola çumurmas kâhnı

Âşık irseng körmegil ey şeh gedâlarnı hakîr

Kim belâlıg 1şk fark itmes gedâ vü şâhnı

Ey Nevâyî yâr işiki pâklerge kıbledür

Kılagıl köz kanıdın âguşte ol dergâhnı (Türkay 2002: 466)

Ayrıca Abdülbakı Gölpınarlı'nın tespitlerine göre Fuzûlî́nin de Ali Şir Nevâi'nin şiirlerine başta Su Kasidesi olmak üzere pek çok nazire yazdığını belirtmek gerekir. Hatta Fuzĥlî Divanı'nında yer alan ilk gazel bile Ali Şir Nevâi'nin,

Aşrakat min aksi şemsü'l-ke'si envârü'l-hüdâ

Yâr aksin meyde kör dip câmdın çıktı sadâ

matla'lı gazeline nazire olarak çıkar. Buna Fuzûlî,

Kad enâre'1-1şk li'l-uşşâkı minhâci'l-hüdâ

Sâlik-i râh-1 hakîkat ışka eyler iktidâ

şeklinde cevap verir. Fars şairlerine de cevaplar yazan Fuzûlî ayrıca Yavuz'un defterdarı olan Hayâlî-i Kadîm'e de nazire yazmıştır.

Harâb olupdur ol âbâd gördüğün gönlüm

Gamunla toptoludur şâd gördügün gönlüm 
Cihânda başına sultân iken benüm servüm

Kul oldı sen şehe âzâd gördügün gönlüm

Cefâya ögrenüben cevre cân virür şimdi

Vefâ vü cevr ile mu'tâd gördüğün gönlüm

Görince dâne-i hâlüni dâm-1 zülfünde

Tutıldı kaldı o sayyâd gördügün gönlüm

Karışdı kara yire kûhsâr-1 mihnetde

Hayâlî şimdi o şeyyâd gördügün gönlüm (Gölpınarlı 1985: XLII)

Hayâlî-i Kadîm'in bu gazeline Fuzûlî,

Tutuşdı gam odına şâd gördügün gönlüm

Mukayyed oldı ol âzâd gördügün gönlüm

Diyâr-1 hicrde seyl-i sitemden oldı harâb

Fezâ-yı 1şkda âbâd gördügün gönlüm

Ne gördi bâdede bilmen ki oldı bâde-perest

Mürîd-i meşreb-i zühhâd gördügün gönlüm

Firâkun odını gördükçe mûm tek eridi

Sebât $\mathrm{u}$ sabra fûlâd gördügün gönlüm

Getürdi acz görüp 1şk müşkil oldugını

Kamu hünerlere üstâd gördügün gönlüm

Degüldi beyle deminde bir ehl-i işret idi

Bu kanlar içmege mu'tâd gördügün gönlüm

Fuzûlî eyledi âheng-i 1yş-hâne-i Rûm

Esîr-i mihnet-i Bagdâd gördügün gönlüm (Fuzûlî 1286: 192;

Gölpınarlı 1985: 110)

gazelini nazire olarak yazmıştır.

Dikkat çeken bir başka durum da yine on altıncı yüzyılın ilk yarısında kendini yetiştirmiş ümmî şairlerden Enverî́nin şiirine yazılan nazireler ve bu nazirelerin birbirini takip edip yirminci yüzyıla kadar gelen 
zamanda, gazel tarzında olduğu gibi, daha başka nazım şekillerinde yeni nazirelerin ortaya konulmasıdır. Gerçekte tezkire yazarları, halk şairlerine eserlerinde yer vermezlerken, ümmî bir şair olan Enverî́yi eserlerine almaları ayrıca düşündürücüdür. Yalnız Enverî’nin bir divana sahip olması ve güzel söyleyişi sayesinde, şairin bir zorlama sonucu bu eserlere girdiğini akla getirmektedir. Bu durumda şair güzel ve yerinde şiirleri ile dikkat çekmiş ve tezkirelere girmeye hak kazanmıştır. Aşağıdaki gazeli Mesihî ve Hatâyî'den başlayarak Süleyman Nazif'e kadar, bütün Türk edebiyatı boyunca gelmektedir. Enverî (ö. 1547)'nin yazdığ1 bu gazel musikimiz açısından da önemli bir yer tutar. Çünkü bu gazel XVIII. yüzyılda Hacı Sadullah Ağa (1730-1801) tarafından da bestelenmiştir (Çeltik 2007: 112 vd.). Şimdi bu gazele bakalım:

N'ideyin sahn-1 çemen seyrini cânânum yok

Bir yanumca salınur serv-i hırâmânum yok

Emdürür gerçi lebin vaslına cânlar virene

Leb-i cân-bahşını emsem dimeğe cânum yok

Bağrumun başına dâğ-1 gamı odlar yakalı

Kaldum ayakda kara başuma dermânum yok

Nice da'vet ideyin ol periyi dâ'ireye

Hâtem-i la'li gibi mühr-i Süleymân'um yok

Enverî gülşen-i kûyunda figânlar eyler

Dime iy gonca-dehen bülbül-i nâlânum yok (Çeltik 207: 112-113)

Enverî́nin gazelini bir tarafa bırakacak olursak, bu şiire dördü matla beytine dayalı iki muhammes, bir müseddes, bir de müsebba, onu da gazel olmak üzere tam on dört nazirenin yazıldığını görürüz. Ancak yazılan nazireler ile Enverî́nin şiirini karşılaştıracak olursak, sonra yaz1lanların asıl zemin şiiri söyleyiş, edâ ve başka yönlerden geçtikleri pek söylenemez (Daha geniş bilgi için bkz. Çeltik 2007).

On altıncı yüzyılın ortalarına kadar yazılan şiirlere bakacak olursak bu zamanda üç nazire mecmuası ile karşılaşırız (Yavuz 2002: 14). Ancak bu nazire mecmualarından başka mecmuaların da varlığı bir gerçektir. 
İçinde Sultan Gavri Divanı'na da yer veren ve Orhan Yavuz tarafindan yayımlanan Kansu Gavrî̀nin Türkçe Divanı adlı esere baktığımızda, M1sır'da hüküm süren ve Mısır'in son hükümdarı olan Kansu Gavrî'nin de onun üstünde şairin şiirine nazire yazdığını görürüz. Bu şairlerin başında meşhur XIV. yüzyıl Azeri şairi Nesimî ile Hasanoğlu da bulunmaktadır. Bundan başka olarak Gavrî; Ahmedi, Zarifî, Nasibî, Şeyhoğlu, Salâhî, Ahmed Paşa, Şirazî, Kâtiboğlu, Karamanlı Nizamî, Halâsi, Cem Sultan gibi şairlere de nazireler yazmıştır. Biz bunlardan Hasanoğlu ile Şeyhoğlu'nun şiirlerine yazdığı nazireleri ve zemin şiirleri aşağıda veriyoruz.

Niçesin gel iy yüzi agum benüm

Sen eritdün odlara yagum benüm

And içerem senden artuh sevmeyem

Senün ile hoş geçer çagum benüm

Hüsn içinde sana mânend olmaya

Aslı yüce gönli alçagum benüm

Al elümi ireyim maksûduma

Koma yürekde yana dagum benüm

Sen rakîbe sırrunı fâş eyledün

Anun-1la oldı ş1ltagum benüm

Kışladum kapunda itlerün ile

Oldı kûyun uşda yaylagum benüm

Men ölicek yolına gömün beni

Bakatursın yâra torpagum benüm

Torpagumdan bite hasretle agaç

Kıla zârî cümle yarpagum benüm

Bu Hasanoğlı senün benden-durur

Anı redd itme yüzi agum benüm

Hasanoğlu'nun bu şiirine Sultan Gavri aşağıdaki gazelle cevab vermiştir: 
İy yüzi gül gülşen ü bâgum benüm Zülfünün zinciridür bağum benüm

Ol kadar ok urdı gamzen bagruma Yüregümde kalmadı yagum benüm

Vasl-1 sinün Tûr-1 Sînâ'dur bana İy dil-ârâm oldı turagum benüm

Sen gelürsen sinüme baş kaldurup Ayaguna düşe topragum benüm

Dilberâ bin hacc u umre sayaram Senün-ile her geçen çagum benüm

Şol kara hâlün gibi hâlî degül Yüregümde dâyimâ dâgum benüm

Görk içinde olmaya hüsnün gibi Kadri yüce gönli alçagum benüm

Husrevâ lutf eyle rahm it Gavri'ye İy gözi nerkis yüzi agum benüm (Yavuz 2002: 105-107)

Ayrıca Şeyhoğlu'nun,

Visâl-i yâra irişdük olur destûr hicrâna

Gönül maksûdına irdi gerekdür câna şükrâne

Zihî devlet sa âdetdür ki şâdî geldi gam gitdi

Ne hoş sa'd ile devrândur fidâdur cân bu devrâna

Ne dilbersin ne serversin Alî heybetlü Haydarsın

Hızır'sın yâhud İskender ki benzersin Süleymân'a

Kapundan sürmegil beni ki cân virdüm işigünde Senünle âşinâdur cân anı sen sanma bîgâne

Niçe yirlerde turışdum niçe yirlerde sorışdum Şükür Tanrı'ya Şeyhoglı bu gün irişdi dermâna 
gazeline karşı Gavrî aşağıdaki nazireyi yazmıştır:

Hezârân şükr ile minnet ki irişdük bu devrâna

Yine evvel bahâr oldı virelüm cânı şükrâne

Cihân bâg-1 cinân oldı hayât-1 câvidân buldı

Yine kutlu zamân oldı irişdi mürdeler câna

Çemenler oldı hep cennet fütûh-ı rûhadur râhat

Gerek ise sana hikmet sehergeh gir gülistâna

Gül ile berg-i nesrînler açılmışdur reyâhînler

Boyanup goncalar kana yatur mahmûr ü mestâne

Kaçurma fursatı elden fenâ olmazdan ön bir dem

Koma peymâneyi elden tolınca tâ ki peymâne

Getür sâkî mey-i bâkî ki arşa uralum sâkı

Mu'attar eyle âfâkı mu'anber zülfe ur şâne

Çalınsun çeng ile neyler bugün ayş itmeyen n'eyler

Hemân tazyî'-i ömr eyler oluban garra devrâna

Ne cân sûretlü dilbersin diyâr içinde dâversin

Ali heybetlü serversin ki sûr-1 pâdişâhâne

Niçe furkat niçe mihnet gelür şâdî gider gussa

Bihamdillâh bugün Gavrî irişdi gene cânâna (Yavuz 2002: 94-96)

Bütün bunlardan başka olarak şathiye şiirlere de nazire yazıldığını belirtmeden geçmemek gerekir. Yunus Emre'nin şathiyesine de nazire yazıldığını görürüz. Yunus'un şiirine bakalım:

Çıkdum erik dalına anda yidüm üzümi

Bostan issi kakıyup dir ne yirsin kozumı

Kerpiç koydum kazana poyraz-1la kaynatdum

Nedür diyü sorana bandum virdüm özini

İplik virdüm çulhaya sarup yumak itmemiş

Becid becid 1smarlar gelsün alsun bizini 
Bir serçenün kanadın kırk katıra yükledüm

Çift dahı çekemedi şöyle kaldı kazanı

Bir sinek bir kartalı salladı urdı yire

Yalan degül gerçekdür ben de gördüm tozını

Bir küt ile güreşdüm elsüz ayağum aldı

Güreşüp basamadum köyindürdi özümi

Kaf tagından bir taşı şöyle atdılar bana

Öglelik yola düşdi bozayazdı yüzümi

Balık kavaga çıkmış zift turşusın yimege

Leylek koduk togurmış baka şunun sözini

Gözsüze fısıldadum sagır sözüm işitmiş

Dilsüz çagırup söyler dilümdeki sözümi

Bir öküz bogazladum kakıldum sere kodum

Öküz issi geldi eydür bogazladun kazumı

Bundan da kurtılmadum n'idesini bilmedüm

Bir çerçi geldi eydür kanı aldun gözgümi

Tospagaya sataşdum gözsüz sepek yoldaşı

Sordum sefer kancaru Kayseri'ye azimi

Yûnus bir söz söyledün hiçbir söze benzemez

Münâfıklar elinden örter ma'nî yüzini (Timurtaş 1980: 226)

Bu şiir daha çok Tevârîh-i Âl-i Osman adlı eseri ile tanınan, şiirlerinde Âşıkî mahlasını kullanan ve Âşık Paşa'nın torunlarından olan Derviş Ahmed tarafından aşağıdaki şekilde tanzir edilmiştir:

Çıkdum bâdem dalına anda yidüm üzümi

Ol dem ki üzüm yidüm mânâ buldum sözümi

Ol bâdem bagçasını varmadın seyrân itdüm

Bostancı bana eydür ne çok yoldun kozumı 
O bana ugrı didi ben ona bühtân itdüm

Bir öküzlü Tatar dir boğazladun kuzumı

Dikilmedük bagçanun bitmedük nârın yidüm

Yükler ile götürdüm doyurmadum özümi

Eğrilmedük ipligi üstâd cullaha virdüm

Üstâd yumak eylerken ben hoş geydüm bizümi

Bir ayyâr ugrı ile ortaklıga barışdum

Üç ol alır bir virmez bana dir hey sözümi

Yügrük kötürüm gördüm gözsüz sıçana uymış

Gâyet becid giderler Kaf Dag1'dur âzimi

Bir dilsüze yol sordum gözsüz yolum bildürdi

Bir sagır tîz işitmiş ol anladı râzumı

O sagır ile dilsüz ikisi beni avlar

Gözsüz arduma düşmiş durmaz izler izümi

Sagır ile dilsüzi o gözsüze gönderdüm

Gözsüz gözüni virdi anda gördüm yüzümi

Kötürümle güreşdüm, elsüz bilüm kavradı

Dürişdüm basamadum koyuvirdüm tazumı

Bu sohbete bir aşçı kırk kazan aş bişürmiş

Suyı hava eti yok tuzı ise tuzumı

$\mathrm{Ol}$ aşçı kazanınun dibi duvarı yokdur

Od yakmadan taşurur kapak ider tozumı

Âşıkî ile Yûnus il bilmez yola gitdi

Münkir olmasun diyü sapdururum izümi (Pekolcay vd. 1991: 63-

Görüldüğü gibi Türk şiirinde on altıncı yüzyıla geçerken nazirelerin yazıldığını, bunlardaki çeşitliliği, bölge ve dildeki farklılıkların gözetilmeden Türk edebiyatında bir bütünlüğün bulunduğunu söylemek gere- 
kir. Tabii bu örnekleri çoğaltabiliriz. Ancak bunları nazire mecmualarından takip etmek, bunlara yeni bilgiler getirerek zenginleştirmek en doğru yoldur.

Ayrıca üzerinde durulması gereken bir başka konu da eserlerin eserlere nazire olarak yazılmasıdır. Nihad Sami Banarlı bunu daha çok Süleyman Çelebi'nin yazdığı Mevlid adı ile bilinen Vesîletü'n-Necât için dile getirmektedir. Banarlı, nazire için, yeniden yaratış veya daha mükemmel hâle koyuş fikrine yer vermiştir. Gerçekten Mevlid'e bakınca Süleyman Çelebi'nin Âşık Paşa'nın Garib-nâme adlı eserinde geçen pek çok beyti yeniden ele alarak daha mükemmel bir hâle koyduğunu görürüz (Yavuz 2007: 61-68). Bunun yanında şairin Erzurumlu Mustafa Darir'in Sîretü'n-Nebî adlı siyerindeki doğum kısmını da ihmal etmediğine şahit oluruz. İşte bütün bunları göz önüne alan Nihad Sami Banarlı Resimli Türk Edebiyatı Tarihi'nde Süleyman Çelebi için; Mevlid'in inanmış şairi Süleyman Çelebi, öyle görünüyor ki Türk nazire edebiyatının da büyük simalarındandır... Hazret-i Muhammed'in doğumu mevzuunda Âmine Hatundilinden söyledikleri bölümlerin birkaç beytiniyan yana getiriyoruz diyerek her iki metinden beşer beyte yer vermektedir. Bunları aşağıya alıyoruz.

Kadı Darîr Mevlid'inden:

Mefâ'îlün mefâ'îlün fe'ûlün

Emine eydür ol dem oldı kim uş

Vücûda gelür Ahmed kudret ile

Susadum su diledüm içmeğe ben

Elüme sundılar kıf şerbet ile

Sovuh kardan dahı ağ $\mathrm{u}$ şekerden

Dahı datludur içdüm lezzet ile

Bu kez bir nûr içinde garka oldum

Bürüdi nûru beni ismet ile

Bir ağ kuş geldi arkamı sığadı

Kanadı birle katı kuvvet ile 
Süleyman Çelebi Mevlid'inden

Fâ‘ilâtün fâ‘ilâtün fâ'ilün

Âmine aydur çü vakt irdi temâm

Kim vücûda gele ol Hak vehbeti

Susadum su diledüm içmekliğe

Virdiler bir kıf ki dolu şerbeti

Kardan ağ idi vü hem soğuk idi

Dahı şîîndi şekerden lezzeti

Sonra gark oldı vücûdum nûr ile

Bürüdi beni o nûrun ismeti

Geldi bir ak kuş kanadıyla benüm

Arkamı sığadı kuvvetle katı

$\mathrm{Bu}$ karşılaştırma sonucunda görülen benzerliklere rağmen Nihad Sami Bey, bununla beraber, Süleyman Çelebi-Darîr benzerliğinde bugün hâlâ kat'î hüküm verebilecek bir aydınlıkta değiliz diyerek çekincesini de belirtmekten geri kalmamıştır (Banarlı 1971: I/484-486). Bu fikirden hareketle mevlid türünde Süleyman Çelebi'nin çektiği çı̆̆ırda edebiyatımızda pek çok mevlid yazılmıştır. Bunlar da Mevlid'in naziresi midir? Bu durum da ayrıca üzerinde düşünülmesi gereken bir başka konudur. Diğer taraftan esere nazire konusunda Şeyh Gâlib'in Hüsn ü Aşk'ına nazireler yazıldığı da bilinmektedir. Refi-i Âmidî'nin Cân u Cânân'1 (Öztoprak 2000) bunlardan biridir.

Yine edebiyatımızda mektup şeklinde aynı konu, aynı kafiye, aynı vezin ve nazım şeklinde yazılan nazireler de vardır. Hafız Ahmed Paşa'nın IV. Murad'a gönderdiği manzum mektup ve padişahın karşıllğında yazdığı mektup buna örnektir. Bu bir noktada tam cevap demektir. Nazire karşılığı olarak kullanılan cevap kelimesi bu yönü ile anlam sınırlarını genişletmiş ve hem nazire hem cevap şeklinde görünmüştür. Bu şiirleri aşağıya alıyoruz. Önce Hâfız Ahmed Paşa aşağıdaki gazeli yazmış ve padişahtan yardım istemiştir (Tosun 2011: 336). 
Aldı etrâfı adû imdâda asker yok mudur

Dîn yolunda baş virür bir merd-i server yok mudur

Hasmı geşt ile oyunda ruh-be-ruh şahmât ider

Cengde at oynadır ferzâne bir er yok mudur

Bir aceb girdâba düşdük çâresiz kaldık meded

Âşinâlar zümresinde bir şinâver yok mudur

Cengde hempâmız olup baş virüp baş almaga

Arsa-i âlemde bir merd-i hüner-ver yok mudur

Def'-i bîdâda tekâsülden garaz ne bilmezüz

Derd-i mazlûmân su'âl olmaz mı mahşer yok mudur

Âteş-i sûzân-1 a'dâya bizimle girmege

Dehr içinde imtihân olmuş semender yok mudur

Dergeh-i Sultân Murâd'a nâmemiz îsâline

Bâd-1 sarsar gibi bir çâbük kebûter yok mudur

Bu manzum mektuba padişahın cevabı da şöyledir (Tosun 2011: 337-338):

Hâfızâ Bagdâd'a imdâd itmege er yok mudur

Bizden istimdâd idersin sende asker yok mudur

Düşmanı mât itmege ferzâneyim ben der idün

Hasma karşı şimdi at oynatmaga yir yok mudur

Gerçi lâf urmakda yokdur sana hem-pâ biliriz

Lîk senden dâd alur bir dâd-güster yok mudur

Merdlik da'vâ idersin bu muhanneslik neden

Havf idersin bârî yanında dilâver yok mudur

Râfızîler aldı Bagdâd'ı tekâsül eyledin

Sana hasm olmaz mı Hazret rûz-ı mahşer yok mudur

Bû-Hanîfe şehrin ihmâlinle vîrân itdiler

Sende âyâ gayret-i dîn ü peyamber yok mudur 
Bî-haberken saltanat ihsân iden Perverdigâr Yine Bagdâd'ı ider ihsân mukadder yok mudur

Rişvet ile cünd-i İslâm'ı perîşân eyledün

İsidilmez mi sanursın bu haberler yok mudur

Avn-1 Hak'la intikâm almaga a'dâdan meger

Bende-i dîrîn vezîr-i dîn-perver yok mudur

Bir Alî-sîret vezîri şimdi serdâr eylerim

Hizr u peygamber mu'în olmaz mı rehber yok mudur

Şimdi hâlimi kıyâs eylersin âyâ âlemi

Ey Murâdî pâdişâh-1 heft kişver yok mudur

Türk edebiyatında ortaya çıkan ve şiirimizi açarak genişleten, edebî faaliyetlerin canlılığını devam ettiren nazirecilik neticesinde yeni eserlerin yazılması da gerekirdi. İşte bunun sonunda Türk edebiyatında nazire mecmuaları ortaya çıkmış oldu. Nazire mecmuaları yazılan şiirleri edebî bir zevke göre ele alıp, onlara ilgi duyarak devam ettiren şairlere yer vermeleri ve sevilen şiirleri ortaya koymaları açısından önemlidir. Her şeyden önce edebiyat tarihinde adları geçmeyen ancak şiirleri ile kendini gösteren, hayatları hakkında bilgimizin bulunmadığı şairlerimizin böyle mecmualarda yer alması edebî zenginliğimizi ve edebî genişliğimizi de göstermektedir. Unutulmuş ve eserleri kaybolmuş bu şairler sayesinde nazire mecmualarımız önemkazanmaktadır. Ancak nazire mecmualarına geçmeden, kimi şairlere yer veren ve onlardan beyitler alan ilk şair ve yazar Şeyhoğlu Mustafa'dır. O Kenzü̈l-Küberâ'sında onun üstünde şairin adını zikretmiş ve şiirlerine yer vermiştir (Yavuz 1991). Fakat sonra yazılan nazire mecmualarında şairlerin ve seçilen şiirlerin sayısı da artmıştır.

Edebiyat tarihimizin kaynaklarından olan nazire mecmuaları daha sonra yerlerini "tezkiretü'ş-şuâra" genel adı ile anılan eserlere bırakacaklardır. Böyle olmakla beraber tezkirelerin yanında hemen her asırda, özellikle on altıncı yüzyıldan sonra daha az görülmüşlerdir. Bunlar Türk şiir zevkinin gelişmesini de gösteren derleme eserlerdir. Bildiğimiz kadarı ile Türk edebiyatında yazılan ilk nazire mecmuası Ömer b. Mezid'in ortaya koyduğu Mecmûatü'n-Nezâir adlı eserdir. Biri İngiltere Londra'da, 
biri Türk Dil Kurumu'nda biri de Atatürk Üniversitesi Karahanoğlu Bağış Kitapları No. 10d 91'de olmak üzere üç nüshası bilinen bu eser, 1436 yılında derlenerek Sultan II. Murad'a sunulmuştur (Karabey 1996: 67 vd.). Mecmûatü'n-Nezâir'de Ömer bin Mezîd 84 şairden 397 şiir almıştır. Nesimî, Ahmedî, Şeyhî gibi önde gelen sanatkârların etkiledikleri ve etkilendikleri şairler bakımından önemlidir. Hatta ilk olması yönü ile çı̆̆ır açıcı bir özelliği de vardır. Bu mecmua üzerinde Mustafa Canpolat çalışmıştır (1982).

Türk edebiyatında Ömer b. Mezîd'in Mecmuatü'n-Nezair'inden sonra yazılan ikinci bir nazire mecmuası daha vardır. Bu mecmuanın derleyici ve derleme tarihi belli değildir. Ancak Şeyhî, Ahmet Paşa, Karamanlı Nizamî, Visâlî, Atâyî, Adnî ve Hafî̀nin şiirlerine yer veren sinırlı bir nazire mecmuasıdır. Şiirlerini aldığı şairlerin hayatlarına bakınca bu mecmuanın 15. yüzyılın sonlarına doğru tertip edildiği söylenebilir. Bu nazire mecmuasının diğerlerinden farkı bölümlere ayrılması ve yedi bölümden meydana gelmesidir. Mecmuanın ilk üç bölümü Şeyhî,'nin, dördüncü beşinci bölümü Ahmet Paşa'nın, altıncı bölümü Karamanlı Nizâmî'nin, yedinci bölümü de Atâî'nin şiirlerine yazılan nazire şiirlerden meydana gelmektedir. Bu mecmua zemin veya model şiir denilen şiirlere göre düzenlenmiştir. Hâlbuki diğer nazire mecmuaları vezin, kafiye ve redif benzerliğine göre tertip edilmişlerdir. Eksik ve seksen yaprak olan eserin başka nüshası da ele geçmemiştir. Adı bile belli olmayan bu nazire mecmuasında yedi şairden 213 şiir alınmıştır (Mermer 2002: 75 vd.). Bu şairler içinde yazdığı 62 nazire ile Visâlî ilk sırayı almaktadır. Hafî́nin ise yalnız bir naziresi vardır.

Mecmûatü'n-Nezâir'den 76 sene sonra 1512 yılında yazılan Câmiü'nNezâir ise daha çok şaire yer vermiş ve 266 şairden 2824 şiir almıştır. Sultan II. Bayezid'in öldüğü ve I. Selim'in tahta çıktığ1 senede yazılan Câmiü'n-Nezâir, Eğirdirli Hacı Kemal'in eseridir. Bu açıdan bakılınca II. Bayezid zamanına kadar gelen edebî verimlerin derlenmiş şeklidir. Mecmuaya alınan şiirler alfabetik bir sıra ile verildiğinden nazım şekilleri karışık olup, gazel, kaside, murabba muhammes, müseddes vs. gibi bir sınıflandırma yapılmamıştır. Bu itibarla aynı durum vezinler için de söz konusudur. Anadolu sahasında yazılan edebî verimler başından itibaren II. Bayezid devri sonuna kadar geçen tam üç yüz yıllık bir za- 
manda bu mecmuada toplanmıştır. Bu itibarla Ahmed Fakih (ö. 1251), Gülşehrî (ö. 1317'den sonra), Âşık Paşa (1272-1332), Yunus Emre (ö. 1320), Nesîmî (ö. 1406) gibi şairlerin şiirleri ayrı bir önem taşır. Ahmet Fakih'in Çarhnâmesi, eksik ve kayıp da olsa, sadece Câmiü'n-Nezâir'de yer almaktadır. Ayrıca Yunus Emre ve Nesîmî gibi şairlerin divanlarında bulunmayan bazı şiirleri de bu mecmuada toplanmıştır. Câmiü'nNezâir üzerinde Yasemin Ertek Morkoç çalışmıştır (2003), (Köksal 2006: 68-69). Eserin Bayezid ve DTCF kütüphanelerinde bulunan iki nüshası vardır. Ancak Bayezid Kütüphanesi'ndeki nüshanın yaprakları yer yer koparılmıştır. DTCF kütüphanesindeki nüsha ise daha az şiire yer vermektedir.

XVI. yüzyılda nazire mecmuaları diğer yüzyıllara göre daha çoktur. Câmiü'n-Nezâir'den başka olarak bu yüzyılda Edirneli Nazmî'nin 1524 yılında yazdığı Mecmaü'n-Nezâir ile Pervane Beg'in 1560 yılında derlediği, kendi adı ile anılan Pervâne Beg Mecmuası vardır. Her iki mecmua da Kanûnî devrinde yazılmıştır. Bunları XVII. yüzyılda Budinli Hisalî́nin 1652 yılında, asrın ortalarında derlediği Metâliü'n-Nezâir'i takip etmiştir (Kaya 2005: 48 vd.).

Sonuç olarak belirtmek gerekirse nazire, Arap edebiyatında Cahiliye devrine kadar giden bir tür olup başka isimlerle de anılmıştır. Arap ve Fars edebiyatına paralel olarak on ikinci yüzyılda Ahmed Yesevî́nin şiirine yazılan nazirelerle Türk şiirinde de yer almıştır. Daha sonra Anadolu'da gelişen Türk edebiyatı Ahmed Yesevî́nin şiirlerine Yunus Emre ile başlayan nazirelerle Anadolu'da Ahmedî, Nesîmî, Şeyhoğlu Mustafa ve Ahmed-i Dâî gibi şairlerle gitgide yayılmıştır. On beşinci yüzyılda gelindiği zaman Şeyhî'nin şiirlerine yazılan nazireler başta Ahmet Paşa, Fatih ve Cem Sultan olmak üzere devam edip gelmiştir. Gerçekten Şeyhî'nin "Kerem" redifli kasidesine yazılan nazireler XVIII. yüzyıla kadar gelmiştir. Nazireler bir ana, temel şiire dayanarak yazıldıklarından ve diğer şairleri aynı vezin konu ve nazım şekillerinde şiir yazmaya yönelttikleri için şairler arası bir bağın kurulmasına da sebep olmuşlardır. Aynı duygu ile şiir yazan şairler şiir yönünden daha iyisini ortaya koymak gibi bir gaye ile edebî yönden kendilerini geliştirmek durumuna da düşmüşlerdir. Bu itibarla şairlerarası yarış edebî verimlerin zenginleşmesine ve çeşitlenmesine de yol açmıştır. 
Ortaya konan bu makalede baştan sona kadar Türk edebiyatında görülen bu şiirlere örnekler verilmiş ve okuyucuya bu örneklerin yerinde gösterilmesi yoluna gidilmiştir. Bunlar hangi şairlerin temel olduklarını sonradan gelenlerin yaptıklarını ve şiirde kendilerini nasıl yetiştirmeleri açısından bir örnek olmaları da mühimdir. Necâtî gibi büyük şairleri takip edenlerin ve bu şairlerin tesirlerinin tarih içindeki devamlılığı da böylece ortaya çıkmıştır. Aslında edebiyatın içinde nazirenin de bir başlangıcı vardır. XV. yüzyıla ışıktutan şairler de olmalıdır. Özellikle "gönül" redifli şiirlerin başlatıcısı bu yüzyılın başlarında ömrünün sonuna gelmiş olan Şeyhoğlu Mustafa'dır. Nazire edebiyatının genişlemeye başlaması daha çok Yıldırım Bayezid'in şehzadesi Emir Süleyman zamaninda olmuştur.

Edebiyatımızda daha sonra başta Süleyman Çelebi olmak üzere mevlidler yazılmıştır. Ancak yazılan mevlidler Süleyman Çelebi'nin eserini hiçbir zaman geçememişlerdir. Şeyhî ile başlayan "kerem" kasideleri zinciri orta çıkmıştır. Necâtî ise XVI. yüzyıla girerken, büyük bir usta şair olarak kendini gösterir. Fuzûlî’den Bâkı'ye, Zâtî de dâhil, onun şiirlerine nazireler yazarlar. Hele onun "Hançer" redifli kasidesi başta Şeyhülislâm Kemalpaşazade olmak üzere, ondan fazla şaire nazire yazdırmıştır. Bu durum Anadolu sahasında paralel olarak Doğu Türkçesinin önde gelen şairleri arasında da kendini gösterir. Ali Şîr Nevâyî de Lütfî́nin şiirlerine nazireler yazar. Aynı durum Mısır'da gelişen Türk edebiyatına da yansır. Sultan Gavri (ö. 1516) de Hasanoğlu'ndan başlayarak, Şeyhoğlu Mustafa gibi şairlerin şiirlerine nazireler yazar. Vezir Hâfız Ahmed Paşa'nın yazdığı şiire IV. Murad Han'ın yazdığı cevap ise, bu türün bir başka tarafını verir. Galib'in şiiri ile övünmesi ve şairlere tenbihi de dikkat çekmektedir.

İşte XII. yüzyılda Türk şiirinde görülmeye başlayan nazire asırlar aşırı bir şekilde günümüze kadar gelmiştir. Ancak XV. yüzyıldan itibaren bu şiirlere yer veren Mecmûatü'n-Nezâir, Câmiü'n-Nezâir ve Mecmaü'n-Nezâir gibi adlarla nazire mecmuaları da ortaya çıkar. Bunlar tezkirelerin başlangıcı olarak görülürler. Bunları başka mecmualar izler. XVI. yüzyılda yazılan Pervâne Beg Mecmuası bunların en önemlilerindendir. XVII. yüzyılda ise "nezâir" kelimesine yer veren Budinli Hisâlî'nin Metâliü'n-Nezâir adlı mecmuası ile karşılaşırız. Ancak artık 
nazire veya nezair kelimesine yer vermeseler bile şiir meraklıları tarafından başka mecmualar da düzenlenir. Bunların sayısı bile belli değildir. Mecmua bakımından kütüphanelerimizin zenginliği ayrı bir önem taşır. Bunlar tertip edildikleri zamana kadar edebiyatımızda dikkat çeken şiirleri barındırmaları ve bir zevk süzgecinden geçirmeleri açısından önemli eserlerdir.

\section{Kaynaklar}

Akdoğan, Yaşar (1979), Ahmedî Divanı ve Dil Hususiyetleri, Basılmamış Doktora Tezi, İ.Ü.Türkiyat Araştırmaları Enstitüsü Kütüphanesi, nu. 2054, İstanbul: c.II.

Akdoğan, Yaşar (1988), Ahmedî Dîvânından Seçmeler, Ankara: KTB Yay.

Arslan, Mustafa (2009), "Necâtî Etkisinin Tespitinde Nazireciliğin Rolü ve Muhyî́nin Necatî́ye Yazdığ1 Nazireler"; Kocaeli Üniversitesi, I. Uluslar arası Türk Dili ve Edebiyatı Sempozyumu, 15-17 Nisan 2009 / 121-131.

Ayan, Hüseyin(1969), Şeyhoğlu Mustafa, Hurşîd-nâme, Erzurum: Atatürk Üniversitesi Yayınları.

Ayan, Hüseyin (1990), Nesîmî Divanı, Ankara: Akçă̆ Yayınevi.

Banarlı, Nihad Sâmi (1971), Resimli Türk Edebiyatı Tarihi İstanbul: MEB Yayınları, c.1.

Bayak, Cemal (1998), Sehâbî Divanı ve Konu İndeksi, İstanbul Üniversitesi Sosyal Bilimler Enstitüsü Basılmamış Doktora Tezi, İstanbul.

Bayram, Yavuz (2009), Sultan II. Bayezid Divanı, Amasya.

Canpolat, Mustafa (1982), Ömer bin Mezid, Mecmuatü'n-Nezâir, Ankara: TDK Yayınları.

Cavanşir, Babek - N. Necef, Ekber (2006), Şah İsmail Hatâ'î Külliyatı, İstanbul.

Cengiz, Halil Erdoğan(1986), "Divan Şiirinde Musammatlar”, Türk Dili, Türk Şiiri Özel Sayısı II, sayı 415-416-417 Temmuz-Ağustos-Eylül, s. 291427.

Çelebioğlu, Amil (1999), Türk Edebiyatında Mesnevi (16. Yüzyıla Kadar), İstanbul: Kitabevi. 
Çeltik, Halil (2007), “Ümmî Şair Enverî’nin Bir Gazeline Nazireler", Gazi Eğitim Fakültesi Dergisi, Özel Sayl, Ankara: Gazi Üniversitesi Yay.

Çiçekler, Mustafa (2006), " Nazire”, DİA, İstanbul: Türkiye Diyanetİşleri Vakf1 Yay., 32/457.

Doğan, Muhammed Nur (2002), Şeyh Gâlib, Hüsn ü Aşk, İstanbul: Ötüken Yayınevi.

Doğan, Muhammed Nur (2004), Fatih Divanı ve Şerhi, İstanbul.

Durmuş, İsmail (2006), " Nazire”, DİA, İstanbul: Türkiye Diyanetİşleri Vakfı Yay., 32/455 vd.

Eraslan, Kemal (1991), Ahmed-i Yesevî, Dîvân-ı Hikmet, Seçmeler, Ankara: Kültür Bakanlığ 1000 Temel eser:

Ersoylu, Halil (1989), Cem Sultân'ın Türkçe Dîvânı, Ankara: TDK Yayınları.

Faruk Timurtaş; Osmanlı Türkçesi Metinleri II, İstanbul 1974, s. 532.

Fuzûlî (1286), Külliyât-ı Divan, İstanbul: Tasvir-i Efkâr Matbaası.

Genç, İlhan (1998), Hoca Neş'et, Hayatı, Edeb̂̂ Kişiliği ve Divanının Tenkitli Metni, İzmir.

Gölpınarlı, Abdülbâki (1985), Fuzûlî Dîvânı, İstanbul: İnkılâp Kitabevi.

Göre, Zehra (2009), "Kerem Kasidelerine Dair”, Atatürk Üniversitesi Türkiyat Araştırmaları Enstitüsü Dergisi, Erzurum:Atatürk Üniversitesi Yay., S. 39/ 919-957.

Gürol, Ayşe (1994), Vak'anüvis Mehmed Pertev Efendi ve Divan I, İstanbul Üniversitesi Sosyal Bilimler Enstitüsü Basılmamış Yüksek Lisans Tezi, İstanbul.

İlaydın, Hikmet (1956), “Kerem" Kasideleri, İstanbul Enstitüsü Dergisi, İstanbul: S. 2 /1-18.

İpekten, Haluk (1974), Karamanlı Nizami, Hayatı, Edebî Kişiliği ve Divanı, Ankara: Sevinç Matbaası, Atatürk Üniversitesi Yayınları.

İpekten, Haluk (2004), Eski Türk Edebiyatı Nazım Şekilleri ve Aruz, İstanbul: Dergâh Yayınları.

İsen, Mustafa - Kurnaz, Cemal (1990), Şeyhî Divan, Ankara: Akçă̆ Yayınları. İslam Âlimleri Ansiklopedisi, İstanbul: Türkiye Gazetesi Yayını, c. 1/332-334, c. 2/14-16.

Karaağaç, Günay (1997), Lütfi Divanı, Ankara: TDK Yayını. 
Karabey, Turgut (1996), "Mecmuatü'n-Nezâir'in Yeni Bir Nüshasına Dair", Atatürk Üniversitesi Türkiyat Araştırmaları Enstitüsü Dergisi, sayı 6, Erzurum: EAÜ Yay., S.6/67 vd.

Karavelioğlu, Murat A.(2011), Mecmua-i Kasâid-i Türkiyye, İstanbul: Titiz Yayınları.

Karayazı, Nurgül (2012); 17. Yüzyıl Şairi Abbas Yârî ve Dîvânı, Marmara Üniversitesi Türkiyat Araştırmaları Enstitüsü, Doktora tezi, İstanbul.

Kaya, Bilgi (2005), "Nazire Mecmuaları ve Hisâlı̄nin Metâli'ü'n-Nezâiri", Uludağ Üniversitesi, Fen-Edebiyat Fakültesi Sosyal Bilimler Dergisi, Bursa: S. $8 / 48$ vd.

Kaya, Önal (1996), Ali Şîr Nevâŷ̂, Fevayyidü'l-kiber, Ankara: Türk Dil Kurumu Yay.

Koç, Mustafa (2011), “Anadolu'da İlk Türkçe Te’lif Eser”, Bilig, Ankara: 57/ 159-172.

Koncu, Hanife (2010), “Klasik Türk Şiirinde Hançer ve Figânî'nin Hançer Redifli Kasidesi Üzerine", Türk KültürüIncelemeleri Dergisi, İstanbul: KOCAV S.23/99-130.

Köksal, Fatih (2006), Sana Benzer Güzel Olmaz, Divan Şiirinde Nazire, Ankara: Akçă̆ Yayınları.

Köseoğlu, Sinan (1997), Zekâyî Divanı, İstanbul Üniversitesi Sosyal Bilimler Enstitüsü Basılmamış Yüksek Lisans Tezi, İstanbul.

Kurnaz, Cemal -Çeltik Halil (2010), Divan Şiiri Şekil Bilgisi, İstanbul: H Yayınları.

Küçük, Sabahattin (1994), Bâkî Dîvânı, Ankara: Türk Dil Kurumu Yayını.

Kürkçüoğlu, Kemal Edib (1973), Tahirü’l Mevlevî, Edebiyat Lugatı, İstanbul: Enderun Kitabevi.

Mermer, Ahmed- Hidayetoğlu, Salahattin - Erdoğan, Mustafa - Koç Keskin, Neslihan (2009), Mecmua-i Medayih-i Mevlâna, Osmanl Şiirinde Mevlana Övgüleri ve Mevlevîlik Unsurlarl, Ankara: Türkiye Diyanet Vakfi.

Mermer, Ahmet (2002), "XV. Yüzyılda Yazılmış Bilinmeyen Bir Nazire Mecmuası ve Aydınlı Visâlî́nin Bilinmeyen Şiirleri", Millî Falklor, , Ankara: S.56. / $75 \mathrm{vd}$.

Morkoç, Yasemin Ertek (2003), Ĕğridirli Hacı Kemal'in Camiü'n-Nezâir'i, Yayınlanmamış Doktora Tezi, Ege Üniversitesi, İzmir. 
Musalı, Vusale (2009), “Necâtî Beg Şiirlerine Yazılmış Nazireler (Latifî Tezkiresi Esasında)", Kocaeli Üniversitesi I. Uluslar Arası Türk Dili ve Edebiyatı Sempozyumu 15-17 Nisan 2009, Kocaeli:309.

Özmen, Mehmet (2001), Ahmed-i Dâi Divanı, I. cilt, Ankara: Türk Dil Kurumu Yayınları.

Pekolcay, Neclâ - Sevim, Emine (1991), Yûnus Emre Şerhleri, Ankara: Kültür Bakanlığı Yayınları.

Sertkaya, Ayşe Gül (2010), "Kul Süleymân (Bakırgani) ve Yûnıs Emre Hikmetleri", İ.Ü. Edebiyat Fakültesi Türk Dili ve Edebiyatı Dergisi, 2008-2, İstanbul: İstanbul Üniversitesi Edebiyat Fak. Yay.

Tarlan, Ali Nihad (1950), Fuzulî Divanı, İstanbul: İstanbul Üniversitesi Yayınları.

Tarlan, Ali Nihad (1992b), Necatî Beg Divanı, İstanbul: Millî Eğitim Basımevi.

Tarlan, Ali Nihad (1970), Zati Divanı, II. Cilt, İstanbul.

Tarlan, Ali Nihad (1992a), Ahmet Paşa Divanı, Ankara: Akçağ Yayınları.

Tarlan, Ali Nihad (2005), Ahmet Paşa Divanı, İstanbul: MEB Yayınları.

Taş, Hakan (2004), Vahyî Divanı ve İncelenmesi, İstanbul Üniversitesi Sosyal Bilimler Enstitüsü Basılmamış Doktora Tezi, İstanbul.

Tavukçu, Orhan Kemal (2009), “Ahmet Paşa'nın “Gönül” Murabbaínın Etkisinde Yazılan Musammatlar", Atatürk Üniversitesi, Fen-Edebiyat Fakültesi, Uluslararası Türklük Bilimi Sempozyumu, Erzurum, 25-27 Nisan 2007, Erzurum: c.2/1015-1020.

Timurtaş, Faruk (1980), Yunus Emre Divanı, Ankara: Kültür Bakanlığ1 Yayınları.

Timurtaş, Faruk K.(1977), Osmanlı Türkçesine Giriş, İstanbul: İ.Ü. Edebiyat Fakültesi Yayınları.

Tosun, Serdal (2011), Hâfız Ahmed Paşa Divanı ve İncelenmesi, İ.Ü. Sosyal Bilimler Enstitüsü, Yüksek Lisans Tezi, İstanbul.

Türkay, Kaya (2002), Ali Şir Nevâyi, Bedâyi 'ü'l-Vasat, Ankara: TDK Yayını.

Yavuz, Kemal (1991), Şeyhoğlu, Kenzü'l-Küberâ ve Mehekkü'l-Ulemâ, Ankara: Atatürk Kültür Merkezi Yayını.

Yavuz, Kemal (2007), “Mevlid'in Türkçe Kaynakları Şerhleri ve Mevlid Metni Üzerine", Uluslararası Süleyman Çelebi ve Mevlid -Yazılışı, Yayılışı ve Etkileri- Sempozyumu 17-19 Ekim 2007, Bursa. 
Yavuz, Kemal (2010), "XIV. Yüzyılda Türk Edebiyatı ve Bazı Dikkatler", Adıyaman Üniversitesi Ulusal Eski TürkEdebiyatı Sempozyumu 15-16 Mayıs 2009, Ankara.

Yavuz, Orhan (2002), Kansu Gavrînnin Türkçe Dîvânı, Konya: Selçuk Üniversitesi Türkiyat Araştırmaları Yayını. 